\title{
Öğretmen Adaylarının Çocuk İstismar ve İhmaline İlişkin Bilgi Düzeyleri ile Çocuğa Yönelik Cinsel İstismarı Bildirme Tutumlarının İncelenmesi
}

\section{Seda DONAT BACIOĞLU* Zöhre KAYA**}

Öz: Bu çalışmada, öğretmen adaylarının çocuk istismar ve ihmaline ilişkin bilgi düzeyleri ile cinsel istismarı bildirmeye yönelik tutumlarının incelenmesi hedeflenmiştir. İlişkisel tarama modeline dayalı olarak yapılan bu çalışma, 2017-2018 eğitim-öğretim yılında Trakya Üniversitesi ve Van Yüzüncü Y1l Üniversitesi (Van YYÜ) Eğitim Fakültelerinde pedagojik formasyon eğitimi alan toplam 515 öğretmen adayı ile yürütülmüştür. Araştırmanın verileri, Öğretmenler için “Çocuk İstismarı ve İhmali Bilgi Düzeyini Tespit Etme Anketi”, Çocuğa Yönelik Cinsel İstismar Tutum Ölçeği ve “Kişisel Bilgi Formu” aracılığıyla toplanmıştır. Analizlerde; betimsel istatistikler, bağımsız gruplar t-testi, tek yönlü varyans analizi ve Pearson korelasyon analizi teknikleri kullanılmıştır. Elde edilen bulgulara göre, öğretmen adaylarının \%87.5’inin çocuk istismarı ve ihmali konusunda bir eğitim almadığı, ihmal ve istismarda risk tanıma ve çocukların davranışsal belirtileri ile ilgili boyutlarda en yüksek ortalamalara sahip oldukları, Van YYÜ’deki öğretmen adaylarının Trakya Üniversitesi’ndeki öğretmen adaylarına oranla, çocuk istismarı ve ihmali konusundaki bilgi düzeylerinin daha az olduğu, Trakya Üniversitesi'ndeki öğretmen adaylarının ise Van YYÜ’deki öğretmen adaylarına oranla istismara ilişkin çocuğun gösterebileceği davranışsal belirtiler konusunda daha fazla bilgi sahibi oldukları bulgusuna ulaşılmıştır. Öğretmen adaylarının cinsel istismarı bildirmeye yönelik tutumlarının düşük düzeyde olduğu, ancak bilgi düzeyleri arttıkça güvenlerinin arttığı ve çocuğa yönelik cinsel istismarı bildirmeye yönelik negatif tutumlarının azaldığ tartış1larak öneriler sunulmuştur.

Anahtar Kelimeler: Öğretmen Adayları, Çocuk İstismarı ve İhmali, Cinsel İstismar, Tutum

*Dr. Öğr. Ü. Trakya Üniversitesi, Eğitim Fakültesi, Eğitim Bilimleri Bölümü, Email; sedadonatbacioglu@trakya.edu.tr, Orcid No: 0000-0001-9901-0601.

Dr. Öğr. Ü. Van Yüzüncü Yıl Üniversitesi, Eğitim Fakültesi, Eğitim Bilimleri Bölümü, Email: zohrekaya@yyu.edu.tr Orcid No: 0000-0001-9211-3632 
The Examination of Prospective Teachers Regarding Their Knowledge Levels of Child Abuse and Neglect and Their Attitudes Towards Reporting Child Sexual Abuse

Abstract: The present study aims to examine the knowledge levels of prospective teachers regarding child abuse and neglect and their attitude towards reporting sexual abuse. Based on relational survey model, this study is conducted with total 515 prospective teachers having pedagogical formation education in Trakya University and Van Yuzuncu Yil University (Van YYU) in 2017-2018 educational year. The data was collected through the Survey for Determining the Knowledge Levels of Teachers about "Child Abuse and Neglect, Attitude Scale towards Child Sexual Abuse”, and “Personal Information Form”. Descriptive statistics, independent samples t-test, one-way analysis of variance and Pearson correlation coefficient tests were used for data analyses. The findings showed that $87.5 \%$ of prospective teachers did not have an education on child abuse and neglect. Also, they had the highest means in dimensions about children's behavioural symptoms and risk recognition in abuse and neglect. On the other hand, the prospective teachers in Van YYU had lower knowledge levels about child abuse and neglect compared to Trakya University. Another finding was the prospective teachers in Trakya University had higher knowledge levels about behavioural symptoms children may show towards abuse than the ones in Van YYU. In conclusion, the study showed that prospective teachers had low levels of attitudes towards reporting sexual abuse, however the more their knowledge level increased, the more their negative attitudes towards reporting child sexual abuse decreased. Study findings were discussed within the framework of literature and some suggestions were made.

Keywords: Prospective teachers, Child Abuse and Neglect, Sex Abuse, Attitude

\section{Giriş}

Çocuk istismarı ve ihmali, ebeveyn ya da çocuğa bakmakla yükümlü kişilerin, çocuk yetiştirme ile ilgili toplum normlarına uymayan şekildeki çeşitli eylem ya da eylemsizliklerinin sonucunda çocuğun kasıtlı olarak zarar görmesidir (Polat, 2001). Fiziksel, duygusal, cinsel istismar ve ihmal olmak üzere dört başlık altında gruplandırılmıştır. Çocuğun fiziksel istismarı, istismar türleri içinde en çok görülen ve daha çabuk anlaşılan bir istismar biçimi iken çocuğun fiziksel ihmali ise, çocuğun beslenme, giyinme, barınma ve tıbbi ihtiyaçlarını karşılamakta yoksun bırakma ya da yetersiz şekilde karşılama şeklinde tanımlanmaktadır (Erermiş, 2001). Çocuğun duygusal gelişimine zarar veren duygusal 
istismar, diğer istismar türlerine eşlik eden ancak anlaşılması en zor istismar türüdür. Çocuğun duygusal ihmali ise, bakım verenin ergen ve çocuklara ruhsal bakımdan hasar veren davranış şekilleri olarak ifade edilmektedir (Polat, 2001). Cinsel istismar ise; kısa ve uzun vadede ağır olumsuz ve onarılması çok güç sonuçların yaşanmasına neden olan ciddi tıbbi, hukuki ve sosyal problemlerden biridir (Çeçen, 2007). Gelişimsel açıdan olgunlaşmamış çocuk ve ergenlerin, yetişkin bir bireyin cinsel doyumuna yönelik tam olarak anlamlandıramadıkları bir eylem içerisinde olmaları çocuk cinsel istismarı olarak tanımlanmaktadır (Aktepe, 2009). Cinsel ihmal de, çocukların cinsel açıdan sömürülmelerine karşı gerekli önlemlerin alınmaması ve korunmalarına yönelik duyarsız olunması, cinsel gelişimlerine gerekli önem ve özenin gösterilmemesi şeklinde açıklanmaktadır (Erdoğan ve Araslan, 2020). İstismar ve ihmal, birlikte kullanılan kavramlar olup istismarın etkin, ihmalin edilgen olması ikisinin farkıdır. Çocuğa yönelik cinsel istismarın genel kanının aksine, önemli bir oranda aile içi bir yetişkin tarafından yapıldığı belirtilmektedir. Öte yandan okulda erişkinlerden, öğretmenlerden veya yaşça büyük çocuklardan istismar gelebilir (Dağlı ve İnanıc1, 2011). Bazı çalışmalardan elde edilen verilere göre, istismara kalkışanların \% 31'inin aileden olduğu, \% 54'ünün aile içinden olmadığı fakat çocuğun bildiği biri tarafindan yapıldığı, yalnızca \% 15’inin tanımadığı biri tarafından gerçekleştirildiği ortaya konulmuştur (Aydemir ve Yurtkulu, 2012). Cinsel istismara maruz kalan bireylerden az sayıda kişinin ilgili birimlere başvurması nedeniyle cinsel istismarın görülme oranı konusunda gerçek istatistiki bilgilere ulaşmak güçleşmektedir (İşeri, 2008). Çocuğa cinsel istismarda bulunan kişinin aileden biri olması da cinsel istismarın ortaya çıkmasını engelleyen önemli bir durumdur (Eren-Gümüş, 2017). Özellikle aile içinden gelen cinsel istismar; sıklıkla görülen ve genellikle yıllarca devam eden bir durum olmakla birlikte, hem utanç hem de suçluluk duygularına neden olduğu için çoğunlukla gizli kalmaktadır (Ovayolu, Uçan ve Serindağ, 2007). Yeterli veri olmamakla birlikte konu ile ilgili yapılan sınırlı sayıdaki çalışmalar ve adli makamlara yansıyan vaka oranlarına bakılarak, cinsel istismarın ülkemizdeki yaygınlığının azımsanmayacak oranlarda olduğu söylenebilir (Dönmez ve arkadaşları, 2014; Gündüz ve Yıldız, 2016 ). Son yıllarda elde edilen verilere göre, Türkiye’de adli makamlara yansıyan cinsel istismar mağduru çocuk sayısı 2014 yılında 74 bin 64 iken, 2016 yılında 83 bin 552'ye yükselmiştir (Asuma ve İmdat, 2018).

Çocuğun cinsel olarak istismar edilmesini etkileyen risk faktörleri arasında çocuğun gelişimsel özellikleri, sürekli bir hastalığının olması ya da fiziksel yetersizliklerinden dolayı 
bakıma muhtaç olması ve çocuğun yaşı bulunmaktadır. Aile ile ilgili etmenler ise, ebeveynlerin genç yaşta anne-baba olmaları, anne-babanın çocukluklarında istismara uğramaları, ebeveyn kaybı, ekonomik sorunlar, alkol ve madde kullanım bozukluğu, ailede psikolojik ya da fiziksel bozukluk olması, anne baba eğitim düzeyi ve ebeveynlik biçimleri, parçalanmış aile, evlilikte yaşanan çatışma ve sorunlar, çocukla sağlısız ilişki kurulması ve anne babalık rolünün yerine getirilememesi ve çocuk sayısının fazlalığı olarak sıralanmıştır (İbiloğlu, Atlı, Oto ve Özkan, 2018; Taner, Çetin, Iş1k ve İşeri, 2015; Taner ve Gökler, 2004). Bu yüzden, çocuğun gelişimsel özellikleri, yaşı, içinde bulunduğu ailevi ve sosyal şartları göz önünde tutularak travmanın tanımlanması ve travmatik olaya verilen tepkilerdeki öznel öğelerin etkisinin değerlendirilmesi gerektiği belirtilmiştir (Simonelli, 2013).

Çocuk ve ergenlerde cinsel istismar sonrasında ortaya çıkan psikolojik etkiler incelendiğinde; erken dönemde anksiyete, korku, öfke, saldırganlık, çökkünlük, gerileme davranışları, kabuslar görme, suça eğilimli hale gelme ve diğerlerine zorbaca davranış sergileme, kendine zarar verme davranışı, stres bozukluğu ve düşük benlik saygısı, ayrılık anksiyetesi, intihara kalkışma, uyum sorunları, içe kapanma, cinsel içerikli ifade ve davranışlar ortaya koydukları gözlenmektedir (Waid-Lindberg ve Mohr, 2019). Cinsel istismarın orta ve uzun dönemlerdeki psikolojik etkilerine bakıldığında; giderek saldırgan davranışlarda artış olması, posttravmatik stres bozukluğu, depresyon ve kaygı bozuklukları, madde bağımlılığı, intihar eğilimi ve düşüncesi, öğrenme güçlüğü, kişilik bozukluğu ve başkalarına istismarda bulunma ihtimalini kapsamaktadır (Aktepe, 2009; İbiloğlu ve ark., 2018; Walker, Freud, Ellis, Fraine ve Wilson, 2017). İstismarın tekrarlanma durumunda ise, psikolojik bozukluk ortaya çıkma ihtimali güçlenmekte ve daha kalıcı etkiler olmaktadır. Aynı zamanda, bireyin sonraki yaşantısında fiziksel ve cinsel istismara uğrama, yani yeniden kurban durumuna düşürülme (revictimization) olasıllğının da yüksek olduğu üzerinde durulmaktadır (Koçtürk ve Bilge, 2017; Walker ve ark., 2017).

Son zamanlarda cinsel istismara uğramış çocuk ve gençlerle ilgili vakalar ülkemizin gündeminde sıklıkla yer almaktadır. Yazılı ve görsel basında yer alan haberlerin toplumda bu konudaki hassasiyeti artırdığı ve tıbbi, hukuki, eğitim ve sosyal hizmet boyutlarında farkındalık oluşturduğu söylenebilir. Özellikle cinsel istismarın ortaya çıkmasında öğretmenlerin önemli bir rol oynadığı görülmektedir. 2017 yılında Saadet öğretmen tarafından ilkokul öğrencisi $6 \mathrm{kız}$ çocuğuna yapılan taciz olayının ortaya çıkarılması (İHA, 2017), yine aynı yıl bir ortaokulda görevli psikolojik danışman tarafindan sınıfta uygulanan 
bir ankette 13 yaşındaki kız çocuğunun arkadaşının babası tarafından cinsel olarak istismar edildiğini yazması sonucu yapılan bildirim ile zanlının tutuklanması (İHA, 2017) 2018 yılında amcası tarafından istismar edilen 12 yaşındaki kız öğrencinin okulda yazdığı notu arkadaşlarının bulup öğretmenlere götürmesiyle ortaya çıkan (Saymaz, 2018) haberler çocukların kendilerine yönelik tehdit durumlarında özellikle öğretmenlerine açıldıklarını göstermektedir. $\mathrm{Bu}$ durum, cinsel istismarın erken tespit edilmesi ve önlenmesinde öğretmenlerin kilit bir role sahip olduklarını açıkça ortaya koymaktadır. Öğretmenlerin, çocuktaki davranışsal değişimleri gözlemleme, istismara zemin hazırlayan risk faktörlerini tanıma, istismarı bildirme ve rehabilitasyon konularında sahip oldukları bilgi ve yeterlilikler oldukça önemlidir (Dilsiz ve Mağden, 2015). Bu sayede öğretmenler, cinsel istismarın açığa çıkması kadar sahip oldukları bilgi ve yeterlilikler ile aileleri ve çocukları eğitebilirler, diğer meslektaşlarına da müşavirlik yapabilirler. Öğretmenlerin çocuk istismarı ve ihmali konusunda donanımlı olması gerektiği bu kadar aşikarken bilgi kaynaklarının nereden ve ne şekilde olacağına dair soruların cevabı henüz net değildir. Öğretmen yetiştiren üniversitelerin Eğitim Fakültelerinde lisans düzeyinde böyle bir zorunlu ders bulunmamaktadır. Bu konudaki çabaların daha çok kişisel düzeyde- internet, konferans, yazılı ve görsel medya, kitap, sivil toplum kuruluşların eğitimleri - olduğu görülmektedir (Erol, 2007). Öğretmenlerin çocuk istismar ve ihmali konusundaki risk tanıma ve bilgi düzeylerini tespit etmek amaciyla yapılan çalışmada (Dilsiz ve Mağden, 2015), öğretmenlerin \% 60’ının istismar ve ihmale uğramış bir çocukla ilgili olarak hangi yasal sorumluluklara sahip olduklarını bilmediği, \% 34'ünün istismar ve ihmal edilmiş çocuklara nasıl yaklaşacaklarını bilmediği, \% 74'ünün bu konularda eğitim almadığını, \% 45'inin herhangi bir kaynaktan bilgi edinmediğini ve \% 80'inin ise konuyla ilgili eğitim almak istediklerini ifade ettikleri görülmüştür.

Ülkemizde, 5237 sayılı Türk Ceza Kanunu’na (TCK) göre, çocuk istismarı ve ihmalini bildirmek zorunludur ve cezai yaptırımı vardır. TCK'nın 279. maddesi ile de bu sorumluluk kamu görevlilerinin tümüne verilmiştir. Ancak öğretmenler için çocuk istismarını bildirimleri ile ilgili olarak ayrı bir kanun ya da düzenleme bulunmamaktadır. Bu nedenle uygulamada, bildirim yasasına rağmen bu sorumluluğun yerine getirilmediği vakalar bulunmaktadır. Bu konuda yapılan çalışmalar, öğretmenlerin istismarın belirtilerini tanıma ve istismar durumunda hangi birimlere bildirmesi gerektiği konusundaki bilgi eksikliğinin bildirimlerin yapılmasının önündeki en önemli engellerden birisi olduğu üzerinde durulmuştur (Farrell ve Walsh, 2010; Kenny, 2004; Pala, 2011; Tugay, 2008). Diğer 
nedenler arasında ise; yanlış bildirim yapma korkusu (Kenny, 2001), emin olamama (Demir, 2012; Tugay, 2008), zamanlama, sisteme yönelik güvensizlik, bildirimin sonucuna yönelik kaygı (Burç ve Güdücü, 2015) olarak sıralanmaktadır. Yapılan başka bir çalışmada (Walsh, Mathews, Rassafiani, Farrell ve Butler, 2012), öğretmenlerin yalnızca \% 24’ünün daha önce cinsel istismarı bildirdikleri görülmüştür. Bildirim yapan bu öğretmenlerin yasal bildirimde bulunma konusunda bilgi sahibi ve sorumluluklarının farkında oldukları, aynı zamanda sisteme güven duydukları ve bildirim sonrasına ilişkin daha olumlu tutumlara sahip oldukları gözlenmiştir. Alanyazında yer alan araştırma sonuçları, öğretmenlerin bilgi ve farkındalık düzeyi arttıkça cinsel istismarı bildirmeye yönelik tutumlarının da arttığını ortaya koymaktadır (Aksel ve Yılmaz-Irmak, 2015; Dilsiz ve Mağden, 2015; Goldman ve Padayachi, 2005; Walsh ve ark., 2012). Bu nedenle bu araştırmada, öğretmen adaylarının çocuk istismar ve ihmali ile ilgili bilgi düzeylerinin ve cinsel istismarı bildirmeye ilişkin tutumlarının incelenmesi hedeflenmiştir. $\mathrm{Bu}$ çalışmanın cinsel istismarın önlenmesi konusunda çok önemli bir role sahip olan öğretmenlerin farkındalıklarının artırılması, cinsel istismarın tespit edilmesi, önleyici ve müdahale çalışmalarına katk1 sağlayacağı düşünülmektedir. Yukarıda belirtilen amaçlar doğrultusunda aşağıda belirtilen sorulara cevap aranmıştır:

1- Öğretmen adaylarının çocuk istismar ve ihmaline dair bilgileri ne düzeydedir?

2- Öğretmen adaylarının çocuk istismar ve ihmaline ilişkin bilgi düzeyleri ile çocuğa yönelik cinsel istismar tutumları arasında anlamlı bir ilişki var mıdır?

3- Öğretmen adaylarının çocuk istismar ve ihmaline ilişkin bilgi düzeyleri ile çocuğa yönelik cinsel istismar tutumları yaş, cinsiyet ve medeni durum değişkenlerine göre anlamlı bir farklılık göstermekte midir?

\section{Yöntem}

\section{Araștırmanın Deseni}

Öğretmen adaylarının çocuk istismar ve ihmaline dair bilgi düzeylerini ve çocuğa yönelik cinsel istismara ilişkin tutumlarını belirlemek amacıyla yapılan bu araştırma, tarama modelinde gerçekleştirilmiş betimsel bir çalışmadır. Tarama modeli, geçmişte ya da halen var olan bir durumu var olduğu şekliyle betimlemeyi amaçlayan araştırma yaklaşımıdır (Karasar, 2010). 


\section{Çalışma Grubu}

Araştırmanın katılımcılarını, 2017-2018 eğitim-öğretim yılında Trakya Üniversitesi ve Van Yüzüncü Yıl Üniversitesi Eğitim Fakültelerinde pedagojik formasyon eğitimi alan öğretmen adayları oluşturmaktadır ( $(\mathrm{n}=515)$. Katılımcıların demografik özellikleri Tablo 1'de yer almaktadır.

Tablo 1. Öğretmen adaylarının demografik özellikleri

\begin{tabular}{|c|c|c|c|c|c|c|c|}
\hline \multirow{3}{*}{$n=515$} & & \multicolumn{6}{|c|}{ Üniversite } \\
\hline & & \multicolumn{2}{|c|}{$\begin{array}{c}\text { Van YYÜ } \\
\text { n=278, \%54 }\end{array}$} & \multicolumn{2}{|c|}{$\begin{array}{l}\text { Trakya Üni. } \\
\text { n=237, \%46 }\end{array}$} & \multicolumn{2}{|c|}{ Toplam } \\
\hline & & $\mathbf{n}$ & $\%$ & $\mathbf{n}$ & $\%$ & $\mathbf{n}$ & $\%$ \\
\hline \multirow{3}{*}{ Yaş } & $20-22$ & 62 & 22 & 103 & 47 & 165 & 33 \\
\hline & $23-26$ & 181 & 66 & 69 & 31 & 250 & 51 \\
\hline & 27 ve üstü & 32 & 12 & 48 & 22 & 80 & 16 \\
\hline \multirow{2}{*}{ Cinsiyet } & Erkek & 154 & 56 & 189 & 80 & 343 & 67 \\
\hline & Kadın & 121 & 44 & 48 & 20 & 169 & 33 \\
\hline \multirow{2}{*}{ Medeni durum } & Evli & 30 & 11 & 188 & 83 & 218 & 43 \\
\hline & Bekar & 248 & 90 & 39 & 17 & 287 & 57 \\
\hline \multirow{2}{*}{ Çocuğunuz var mı? } & Var & 18 & 7 & 28 & 12 & 46 & 9 \\
\hline & Yok & 243 & 93 & 205 & 88 & 448 & 91 \\
\hline \multirow{2}{*}{$\begin{array}{l}\text { Çocuk istismarı ve ihmali ile ilgili eğitim } \\
\text { alma durumu }\end{array}$} & Aldım & 49 & 18 & 15 & 6 & 64 & 13 \\
\hline & Almadım & 228 & 82 & 219 & 94 & 447 & 88 \\
\hline \multirow{5}{*}{$\begin{array}{l}\text { Çocuk istismarı ve ihmali ile ilgili bilgi } \\
\text { düzeyiniz }\end{array}$} & Çok az & 6 & 3 & 5 & 2 & 11 & 2 \\
\hline & $\mathrm{Az}$ & 43 & 17 & 30 & 13 & 73 & 15 \\
\hline & Kismen & 53 & 21 & 67 & 30 & 120 & 25 \\
\hline & Fazla & 131 & 53 & 116 & 51 & 247 & 52 \\
\hline & Çok fazla & 15 & 6 & 10 & 4 & 25 & 5 \\
\hline
\end{tabular}

Tablo 1 incelendiğinde, araştırmaya katılan toplam 515 öğretmen adayının \% 51’i (n=250) 23-26 yaş, \% 33’ü $(n=165)$ 20-22 yaş, \%16’sı ise 27 ve üstü yaş aralığında yer almaktadır. Katılımcıların \%67'si (n=343) erkek, \% 33'ü (n=169) kadın; \% 43'ü (n=218) evli ve \% 9’u (n=46) çocuklu ve \% 57’si (n=287) de bekârdır. Öğretmen adaylarının \% 88’i $(n=447)$ çocuk istismarı ve ihmali ile ilgili eğitim almadığını, \% 13’ü $(n=64)$ ise eğitim aldığını bildirmiştir. Katılımcıların \% 52’si (n=247) çocuk istismarı ve ihmali ile ilgili bilgi düzeyini "fazla" olarak değerlendirdikleri \% 25’inin $(\mathrm{n}=120)$ kendini "k1smen bilgili”, \% 15’inin (n=73) “az bilgili”, \% 5’inin ( $\mathrm{n}=25)$ “çok fazla bilgili”, \% 2’sinin ise “çok az bilgili” değerlendirdikleri görülmüştür.

\section{Veri Toplama Araçları}

\section{Öğretmenler için Çocuk İstismarı ve İhmali Bilgi Düzeyini Tespit Etme Anketi:} Öğretmenlerin bilgi düzeylerini belirlemek üzere Dilsiz ve Mağden (2015) tarafindan hazırlanan bu anket formunda; ihmal, fiziksel istismar, cinsel istismar, ihmal ve istismarda risk tanıma ve çocukların davranışsal belirtileri ile ilgili toplam 53 madde yer almaktadır. 
Anketin Cronbach Alpha iç güvenirlik katsayısı 0.78 olarak tespit edilmiştir (Bağdaş ve ark., 2016). Bu çalışma kapsamında; ihmal, cinsel istismar, istismar ve ihmalde risk tanıma ve çocukların davranışsal belirtileri ile ilgili toplam 48 madde kullanılmıştır.

Çocuğa Yönelik Cinsel İstismar Tutum Ölçeği: Choo, Walsh, Chinna ve Tey (2013) tarafından geliştirilen ve Akın ve arkadaşları (2013) tarafından Türkçeye uyarlanan ölçek, öğretmenlerin çocukların cinsel istismarına karşı tutum düzeylerini belirlemeye yönelik geliştirilmiş bir ölçme aracıdır. Bu ölçek dört boyuttan (değer, kaygı, yükümlülük, güven) ve sekiz maddeden oluşmaktadır. 5'li likert tipi bu ölçekte yükselen puanlar yüksek düzeyde negatif tutumları göstermektedir. Yapı geçerliği için uygulanan doğrulayıcı faktör analizinin ölçeğin orijinal formundaki gibi iyi uyum verdiği belirtilmiştir $\left(x^{2}=23.91, \quad s d=14\right.$, RMSEA=.047, NFI=.98, IFI=.99, CFI=.99, GFI=.98, SRMR=.023). Ölçeğin iç tutarlılık güvenirlik katsayıları değer alt boyutu için .88, kaygı alt boyutu için .75, yükümlülük alt boyutu için .87 ve güven alt boyutu için .58’dir.

Kişisel Bilgi Formu: Öğretmen adaylarının yaşı, cinsiyeti, medeni durumu, çocuk sahibi olup olmama durumu, çocuk cinsel istismarı ile ilgili eğitim alma durumu ve çocuğa yönelik ihmal ve istismar ile ilgili sahip olduğu bilgi düzeyini derecelendirmesi ile ilgili bilgilerin elde edildiği soruların yer aldığı bilgi formudur.

\section{Verilerin Analizi}

Verilerin analizinde; öğretmen adaylarının demografik özelliklerinin incelenmesinde frekans dağılımı, aritmetik ortalama, standart sapma gibi betimsel istatistikler kullanılmıştır. “Çocuğa Yönelik Cinsel İstismar Tutum Ölçeği' ile ulaşılan veriler normal dağılım gösterdiğinden parametrik yöntemler kullanılmıştır. Çalışmada değişkenler arasındaki ilişki Pearson korelasyon analizi ile, ölçek puanlarının demografik özelliklere göre farklılık gösterip göstermediği ise bağımsız gruplar t testi ve ANOVA ile analiz edilmiştir. Verilerin analizi SPSS 23 programı ile çalışılmıştır.

\section{Bulgular}

Bu bölümde, ölçme araçlarından elde edilen bulgulara ve yorumlarına yer verilmiştir. Bulguların sunuluşunda alt problemlere ilişkin sıralama temel alınmıştır.

Alt problem 1. Öğretmen adaylarının çocuk istismar ve ihmaline ilişkin bilgileri ne düzeydedir? 
Öğretmen adaylarının çocuk istismarı ve ihmali konusundaki bilgi düzeylerini tespit etmek üzere uygulanan ankete verdikleri yanıtların aritmetik ortalamaları ve standart sapmaları Tablo 2'de gösterilmiştir.

Tablo 2. Öğretmen adaylarının anket maddelerine katılım düzeyleri

\begin{tabular}{|c|c|c|c|c|c|c|}
\hline \multirow{3}{*}{ Anket maddeleri } & \multicolumn{6}{|c|}{ Üniversite } \\
\hline & \multicolumn{2}{|c|}{ Van YYÜ } & \multicolumn{2}{|c|}{ Trakya Ünv. } & \multicolumn{2}{|c|}{ Toplam } \\
\hline & $\overline{\mathrm{X}}$ & ss & $\overline{\mathrm{X}}$ & ss & $\overline{\mathrm{X}}$ & ss \\
\hline \multicolumn{7}{|l|}{ İhmal ile ilgili maddeler } \\
\hline $\begin{array}{l}\text { 1-Çocukta büyüme ve gelişme geriliğinin } \\
\text { olmas1, çocukta ihmal belirtisi olarak } \\
\text { düşünülebilir. }\end{array}$ & 2.11 & .95 & 3.62 & .99 & 2.81 & 1.23 \\
\hline $\begin{array}{l}\text { 2-Çocuğun kötü hijyene sahip olması, } \\
\text { çocukta ihmal belirtisi olarak düşünülebilir. }\end{array}$ & 1.85 & .84 & 4.32 & .70 & 2.99 & 1.46 \\
\hline $\begin{array}{l}\text { 3-Çocuğun aşılarının yaptırılmaması veya } \\
\text { geciktirilmesi ihmal belirtisi olabilir. }\end{array}$ & 1.81 & .93 & 4.49 & .79 & 3.04 & 1.60 \\
\hline $\begin{array}{l}\text { 4-Çocuğun yüzünün donuk ve ifadesiz } \\
\text { görülmesi, çocukta ihmal belirtisi olabilir. }\end{array}$ & 2.14 & .93 & 3.56 & .94 & 2.80 & 1.17 \\
\hline $\begin{array}{l}\text { 5-Çocuğun sürekli ve tutarlı bir gözetiminin } \\
\text { olmaması ihmal belirtisi olabilir. }\end{array}$ & 2.09 & .88 & 3.91 & .88 & 2.93 & 1.26 \\
\hline $\begin{array}{l}\text { 6-Çocuğun sağlık sorunlarının } \\
\text { edilmemesi ihmal belirtisi olabilir. }\end{array}$ & 1.66 & .84 & 4.55 & .83 & 2.99 & 1.67 \\
\hline $\begin{array}{l}\text { 7-Çocukta yeme bozukluğu, huzursuz uyuma } \\
\text { görülmesi ihmal olasılığını akla getirmez.* }\end{array}$ & 3.17 & 1.28 & 2.58 & 1.21 & 2.90 & 1.28 \\
\hline $\begin{array}{l}\text { 8-Velilerin çocuklarının öğrenim ve genel } \\
\begin{array}{l}\text { durumlarının görüşüldüğ̈̈ } \\
\text { gelmemesi ihmali akla getirmez. }\end{array}\end{array}$ & 3.68 & 1.26 & 1.95 & 1.04 & 2.88 & 1.45 \\
\hline \multicolumn{7}{|l|}{ Cinsel istismar belirtilerini bilme } \\
\hline $\begin{array}{l}\text { 9-Cinsel istismara uğramış çocukta; cinsel } \\
\text { bölgede acı, yanma, kaşıntı şişlik oluşabilir. }\end{array}$ & 1.85 & .78 & 4.26 & .75 & 2.96 & 1.43 \\
\hline $\begin{array}{l}\text { 10-Çocuk, fiziksel temasa uğramadan da } \\
\text { cinsel olarak istismar edilmiş olabilir. }\end{array}$ & 1.75 & .85 & 4.43 & .74 & 2.98 & 1.56 \\
\hline $\begin{array}{l}\text { 11-Cinsel istismara uğrayan çocukların } \\
\text { önemli bir bölümü fiziksel istismara da } \\
\text { uğramıştır. }\end{array}$ & 1.85 & .77 & 4.22 & .70 & 2.94 & 1.40 \\
\hline $\begin{array}{l}\text { 12-Cinsel istismara uğramış çocukta, beden } \\
\text { eğitimi derslerine katılımda isteksiz } \\
\text { davranmak gibi bazı fiziksel etkinliklere } \\
\text { girişmede isteksizlik olabilir. }\end{array}$ & 2.14 & .88 & 4.00 & .79 & 3.00 & 1.25 \\
\hline $\begin{array}{l}\text { 13-Cinsel istismara uğramış çocuk kendisine } \\
\text { dokunulmasına olağan dışı tepki gösterebilir. }\end{array}$ & 1.72 & .82 & 4.52 & .71 & 3.01 & 1.59 \\
\hline $\begin{array}{l}\text { 14-Kı çocuklarda, özellikle } \\
\text { yanında güvensizlik ve kaygı } \\
\text { görülmesin } \\
\text { cinsel istismar belirtisi olabilir. }\end{array}$ & 2.09 & .84 & 4.06 & .83 & 3.00 & 1.29 \\
\hline $\begin{array}{l}\text { 15-Cinsel istismara uğramış çocuk, kendi } \\
\text { dünyasına çekilip, diğerlerinden kendini } \\
\text { izole eden ve daha önce rastlanmayan } \\
\text { davranışlar sergileyebilir. }\end{array}$ & 1.78 & .75 & 4.41 & .53 & 2.99 & 1.47 \\
\hline $\begin{array}{l}\text { 16-Kendisinin, diğer çocukların veya ana- } \\
\text { babasının cinsel organlarına karşı aşııı merak } \\
\text { ve ilgi gösterme, çocukta cinsel istismar } \\
\text { belirtisi olabilir. }\end{array}$ & 2.75 & 1.02 & 3.19 & .90 & 2.95 & .99 \\
\hline 17-Cinsel ilişkiyi taklit etme, yaşından & 2.54 & 1.04 & 3.46 & .94 & 2.96 & 1.10 \\
\hline
\end{tabular}


beklenmeyecek cinsel bilgiye veya kelime dağarcığına sahip olma, çocukta cinsel istismar belirtisi olabilir.

18-Başkalarına yönelik cinsel içerikli saldırgan davranışlarda bulunma, çocukta cinsel istismar belirtisi olabilir.

19-Çocuğun beklenilen dönemden daha önce mastürbasyona başlaması, çocukta cinsel istismar belirtisi olabilir.

.88

3.75

.74

2.99

1.08

2.6

.97

3.24

.94

2.93

20-Çocukta kakasını tutma davranışı ve sürekli kabızlık şikâyetinin olması, çocukta cinsel istismar belirtisi olabilir.

$\begin{array}{llllllll}3.07 & 1.09 & 2.92 & .94 & 3.00 & 1.03\end{array}$

21-Cinsel istismara uğramış her çocuk, yaşadıklarından dolayı mutlaka belirti ortaya koyar.*

22-Tuvalet eğitimini kazanmış olmasına karşın, çocuğun idrarını veya kakasını kaçırmaya başlaması, çocukta cinsel istismar belirtisi olabilir.

23-Çocuğun eve dönmek istememesi, ev içi istismar1 akla getirebilir.

3.07

1.09

2.92

3.00

24-Çocukta okul başarısında azalma ve derslere karşı ilgisizlik, çocukta istismar belirtisi olabilir.

25-Çocukta ders dişı etkinliklere karşı ilgisizlik, okulu terk etme, çocukta istismar belirtisi olabilir.

2.03

1.01

3.96

.92

2.92

1.36

1.01

3.25

.96

3.03

1.01

2.32

2.32

1.01

3.89

.79

3.04

1.20

2.55

1.03

3.53

.91

3.00

1.09

2.63

1.04

3.46

.92

3.01

1.07

\section{Istismar ve ihmalde risk tanıma}

\begin{tabular}{|c|c|c|c|c|c|c|}
\hline $\begin{array}{l}\text { 26-İstismar ve/veya ihmale uğrayan çocuğun } \\
\text { özsaygısında herhangi bir değişiklik olmaz.* }\end{array}$ & 4.15 & 1.09 & 1.45 & .72 & 2.91 & 1.64 \\
\hline $\begin{array}{l}\text { 27-İstismar ve/veya ihmale uğrayan çocuklar } \\
\text { hiperaktif davranışlar gösterebilirler. }\end{array}$ & 3.25 & 1.12 & 2.83 & 1.06 & 3.06 & 1.11 \\
\hline $\begin{array}{l}\text { 28-İstismar ve/veya ihmale uğramaları, } \\
\text { çocukların okul başarılarını etkilemez.* }\end{array}$ & 4.39 & .90 & 1.43 & .76 & 3.03 & 1.70 \\
\hline $\begin{array}{l}\text { 29-İstismar ve/veya ihmale } \\
\text { çocuklar, uğrayan } \\
\text { yetişkinlerden korkma ve kaçınma gibi } \\
\text { davranışlar gösterebilirler. }\end{array}$ & 1.68 & .88 & 4.46 & .69 & 2.96 & 1.60 \\
\hline $\begin{array}{l}\text { 30-İstismar ve/veya ihmale uğrayan } \\
\text { çocuklar, ağrı verici uyaranlara ve travmalara } \\
\text { karşı aşırı tepkilidirler. }\end{array}$ & 1.91 & .82 & 4.04 & .82 & 2.89 & 1.34 \\
\hline $\begin{array}{lllr}\text { 31-İstismar } & \text { ve/veya } & \text { ihmale } & \text { uğramış } \\
\text { çocuklarda } & \text { intihar } & \text { girişimleri } & \text { ile } \\
\text { karşılaşılabilir. } & & & \\
\end{array}$ & 1.76 & .74 & 4.31 & .65 & 2.93 & 1.45 \\
\hline $\begin{array}{l}\text { 32-İstismar ve/veya } \begin{array}{r}\text { ihmale } \\
\text { çocuklar, göz göramış } \\
\text { siklıkla kaçınırlar. }\end{array} \\
\text { iletişime }\end{array}$ & 1.94 & .81 & 4.21 & .69 & 2.98 & 1.36 \\
\hline $\begin{array}{lcr}\text { 33-İstismar ve ihmale } & \text { uğramış } \\
\text { çocuklarda/ergenlerde } & \begin{array}{c}\text { ilaç } \\
\text { bağımlılığına daha sık rastlanır. }\end{array} & \text { alkol } \\
\end{array}$ & 2.28 & .91 & 3.80 & .86 & 2.98 & 1.17 \\
\hline $\begin{array}{l}\text { 34-Çocukluğunda istismar ve/veya ihmale } \\
\text { uğramış olan ana-babaların çocuklarını } \\
\text { istismar ve/veya ihmal etme olasılıkları daha } \\
\text { düşüktür. }\end{array}$ & 2.88 & 1.17 & 3.00 & 1.00 & 2.94 & 1.10 \\
\hline $\begin{array}{l}\text { 35-Bebeklerin istismara uğrama riskleri } \\
\text { azdır.* }\end{array}$ & 3.56 & 1.16 & 2.22 & .96 & 2.94 & 1.26 \\
\hline
\end{tabular}


36-Ailesinde alkol ve uyuşturucu problemi olan çocuklar, istismar ve/veya ihma açısından risk altındadırlar.

$\begin{array}{llllll}2.02 & .98 & 3.99 & .91 & 2.92 & 1.37\end{array}$
37-Aşırı 1srarcı tutum içinde olan anababalar, çocuklarını daha çok istismar 2.79 ederler.

38-Çocukta zihinsel veya fiziksel engelin ya da davranıs problemlerinin olması, istismar ve/veya ihmal riskini arttırır.

39-Ana-babanın çocuktan gerçekçi olmayan beklentilerinin olması, çocuğunu istismar etme riskini arttırır.

\begin{tabular}{|c|c|c|c|c|c|c|}
\hline $\begin{array}{l}\text { 40-Ana-babanın yaşının çocuk istismar } \\
\text { ve/veya ihmalinde önemi yoktur.* }\end{array}$ & 3.32 & 1.30 & 2.82 & 1.22 & 3.09 & 1.28 \\
\hline $\begin{array}{l}\text { 41-Doğumlar arası sürenin kisa olması, } \\
\text { çocuğun istismar ve/veya ihmale uğramasını } \\
\text { etkileyen bir faktördür. }\end{array}$ & 3.14 & 1.11 & 2.98 & 1.11 & 3.06 & 1.11 \\
\hline $\begin{array}{l}\text { 42-Ana-babanın çocuktan sık sık yakınması, } \\
\text { istismarı akla getirebilir. }\end{array}$ & 3.05 & 1.05 & 2.97 & .97 & 3.02 & 1.02 \\
\hline $\begin{array}{l}\text { 43-Çocuğun cinsiyetinin istismar ve/veya } \\
\text { ihmal edilmesinde önemi yoktur.* }\end{array}$ & 3.27 & 1.45 & 3.06 & 1.54 & 3.18 & 1.49 \\
\hline $\begin{array}{l}\text { 44-Ailedeki çocuk sayısının istismar ve/veya } \\
\text { ihmal edilmesinde önemi yoktur.* }\end{array}$ & 3.37 & 1.16 & 2.63 & 1.07 & 3.03 & 1.18 \\
\hline $\begin{array}{l}\text { 45-Ailenin geniş ya da çekirdek aile } \\
\text { oluşunun, çocuğun istismar ve/veya ihmal } \\
\text { edilmesinde önemi yoktur. }\end{array}$ & 3.22 & 1.18 & 2.80 & 1.08 & 3.02 & 1.15 \\
\hline $\begin{array}{l}\text { 46-Ana ya da babadan birinin olmaması, } \\
\text { çocuk istismar ve/veya ihmali için bir risktir. }\end{array}$ & 2.33 & 1.03 & 3.61 & .99 & 2.92 & 1.20 \\
\hline $\begin{array}{l}\text { 47-Çocuk istismar ve/veya ihmaline üst } \\
\text { sosyo-ekonomik düzeylerde rastlanmaz.* }\end{array}$ & 3.72 & 1.08 & 2.08 & .90 & 2.97 & 1.29 \\
\hline $\begin{array}{l}\text { 48-Ailenin gelir düzeyi, çocuk istismar } \\
\text { ve/veya ihmalinde önemli bir etkendir. }\end{array}$ & 2.85 & 1.14 & 2.87 & 1.11 & 2.86 & 1.12 \\
\hline
\end{tabular}

$(*)$ Ters maddeleri göstermektedir.

Tablo 2’ye göre, çocuk ihmaliyle ilgili olarak öğretmen adayları toplamda en yüksek “Çocuğun aşılarının yaptırılmaması veya geciktirilmesi ihmal belirtisi olabilir” maddesine katılım gösterirken $(\overline{\mathrm{X}}=3.04$, ss=1.60), en düşük “Çocuğun yüzünün donuk ve ifadesiz görülmesi çocukta ihmal belirtisi olabilir” maddesine katılım gösterdikleri görülmektedir $(\overline{\mathrm{X}}=$ 2.80, ss=1.17). Çocuk ihmali ile ilgili üniversiteler arası bir karşılaştırma yapıldığında ise; Van YYÜ öğretmen adaylarının en yüksek katılım gösterdikleri madde ( $\overline{\mathrm{X}}=3.68$, ss=1.26) "Velilerin çocuklarının öğrenim ve genel durumlarının görüşüldüğü toplantılara gelmemesi ihmali akla getirmez" iken Trakya Üniversitesi'ndeki öğretmen adaylar söz konusu maddeye düşük düzeyde katılım gösterdikleri görülmüştür ( $\overline{\mathrm{X}}=1.95$, ss=1.04). Öte yandan Trakya Üniversitesi'ndeki öğretmen adaylarının en yüksek katılım gösterdikleri ( $\overline{\mathrm{X}}=4.55$, ss=.83) “Çocuğun sağlık sorunlarının tedavi edilmemesi ihmal belirtisi olabilir” maddesine Van YYÜ öğretmen adaylarının düşük düzeyde katıldıkları $(\overline{\mathrm{X}}=1.66, \mathrm{ss}=.04)$ görülmüştür. 
Öğretmen adaylarının cinsel istismarın belirtilerini bilme ile ilgili maddelerden toplamda en yüksek katılım gösterdikleri madde "Çocuğun eve dönmek istememesi, ev içi istismarı akla getirebilir” ( $\overline{\mathrm{X}}=3.04, \mathrm{ss}=1.20)$, en düşük katılım gösterdikleri madde ise "Cinsel istismara uğramış her çocuk, yaşadıklarından dolayı mutlaka belirti ortaya koyar” ( $\overline{\mathrm{X}}=2.92$, ss=1.36) olduğu görülmektedir. Cinsel istismarın belirtileri ile ilgili üniversiteler arası bir karşılaştırma yapıldığında ise; Van YYÜ öğretmen adaylarının en yüksek ancak Trakya Üniversitesi öğretmen adaylarının en düşük katılım gösterdikleri madde "Çocukta kakasını tutma davranışı ve sürekli kabızlık şikâyetinin olması, çocukta cinsel istismar belirtisi olabilir" olmuştur $(\overline{\mathrm{X}}=3.07$, ss=1.09; $\overline{\mathrm{X}}=2.92, \mathrm{ss}=.84)$. Trakya Üniversitesi öğretmen adaylarının en yüksek katılım gösterdiği bu kez Van YYÜ öğretmen adaylarının en düşük katılım gösterdikleri madde ise "Cinsel istismara uğramış çocuk kendisine dokunulmasına olağan dişı tepki gösterebilir” olmuştur $(\overline{\mathrm{X}}=4.52$, ss=.71; $\overline{\mathrm{X}}=1.72$, ss=.82).

Öğretmen adaylarının istismar ve ihmalde risk tanıma ile ilgili maddelerden toplamda en yüksek katılım gösterdikleri madde "Çocuğun cinsiyetinin istismar ve/veya ihmal edilmesinde önemi yoktur" iken en düşük madde "Çocukta zihinsel veya fiziksel engelin ya da davranış problemlerinin olması, istismar ve/veya ihmal riskini arttırır" olduğu görülmektedir ( $\overline{\mathrm{X}}=3.18$, ss=1.49; $\overline{\mathrm{X}}=2.82, \mathrm{ss}=1.21$ ). İstismar ve ihmalde risk tanıma ile ilgili üniversiteler arası bir karşılaştırma yapıldığında ise; "İstismar ve/veya ihmale uğramaları, çocukların okul başarılarını etkilemez" maddesine Van YYÜ öğretmen adaylarının en yüksek düzeyde katılarak ( $\overline{\mathrm{X}}=4.39$, ss=.09) istismara uğrayan ya da ihmal edilen çocukların okul başarısının durumdan etkilenmeyeceğini düşünürken iken Trakya Üniversitesi’ndeki öğretmen adaylar söz konusu maddeye en düşük düzeyde katılım göstererek çocukların okul başarısının bu durumdan etkileneceğini düşündükleri görülmüştür ( $\overline{\mathrm{X}}=1.43$, ss=.76). Öte yandan, istismar ve ihmalde risk tanımayla ilgili olarak "İstismar ve/veya ihmale uğrayan çocuklar, ana-babalarından ve diğer yetişkinlerden korkma ve kaçınma gibi davranışlar gösterebilirler" maddesine Van YYÜ öğretmen adayları en düşük düzeyde ( $x=1.68, \mathrm{ss}=.88)$ katılırken Trakya Üniversitesi öğretmen adayları en yüksek düzeyde katılım göstermişlerdir $(\overline{\mathrm{X}}=4.46, \mathrm{ss}=.69)$.

Alt Problem 2. Öğretmen adaylarının çocuk istismar ve ihmaline ilişkin bilgi düzeyleri ile çocuğa yönelik cinsel istismar tutum düzeyleri arasında anlamlı bir ilişki var midır? 
Bu madde kapsamında önce, öğretmen adaylarının çocuk istismar ve ihmaline ilişkin bilgi düzeyleri ile çocuğa yönelik cinsel istismar tutum düzeylerine ilişkin tanımlayıcı istatistikler Tablo 3 'te sunulmuştur.

Tablo 3. Öğretmen adaylarının çocuk istismar ve ihmali bilgi düzeyi ile çocuğa yönelik cinsel istismar tutum düzeylerine ilişkin betimleyici istatistikler

\begin{tabular}{lccccc}
\hline & Ortalama & Std. Sapma & Düzey \% & Çarpıklık & Basıklık \\
\hline Çocuk İstismarı ve İhmali Bilgi Düzeyi & 2.98 & .69 & 59.64 & .09 & -1.24 \\
\hline Yükümlülük & 1.22 & .39 & 24.31 & 1.68 & 1.72 \\
Kayg1 & 1.69 & .81 & 33.83 & 1.23 & 1.10 \\
Değer & 1.23 & .42 & 24.70 & 1.72 & 2.35 \\
Güven & 2.34 & .80 & 46.80 & .52 & .70 \\
Çocuğa Yönelik Cinsel İstismar Tutum & 1.62 & .40 & 32.41 & .71 & .18 \\
\hline
\end{tabular}

Tablo 3'de görüldüğü üzere, öğretmen adaylarının Çocuk İstismarı ve İhmali Bilgi

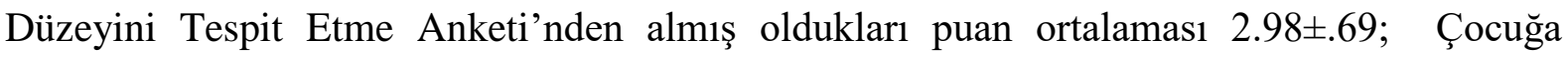
Yönelik Cinsel İstismar Tutum Ölçeği’nden almış oldukları negatif tutum puan ortalaması ise

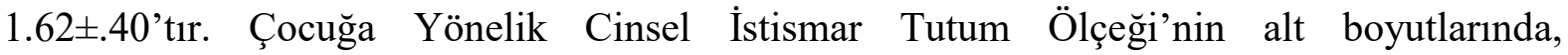
yükümlülüğe ilişkin negatif tutum puan ortalaması $1.22 \pm .39$, kayg1 puan ortalaması $1.69 \pm .81$, değere ilişkin negatif tutum puan ortalaması $1.23 \pm .42$ ve güvene ilişkin puan ortalaması $2.34 \pm .80$ 'dir. Öğretmen adaylarının, çocuk istismar ve ihmaline ilişkin bilgi düzeyleri \% 60 iken çocuğa yönelik cinsel istismara ilişkin tutum düzeyleri \% 32'dir. Bu sonuç, öğretmen adaylarının her ne kadar çocuk istismarı ve ihmali konusunda bilgileri olsa da cinsel istismarı bildirmeye yönelik tutumlarının düşük olduğu şeklinde yorumlanabilir.

Öğretmen adaylarının çocuk istismarı ve ihmaline ilişkin bilgi düzeyleri ile çocuğa yönelik cinsel istismar tutum düzeyleri arasındaki ilişkiye ait korelasyon analizi Tablo 4'de gösterilmiştir.

Tablo 4. Öğretmen adaylarının çocuk istismarı ve ihmaline ilişkin bilgi düzeyleri ile çocuğa yönelik cinsel istismar tutum düzeyleri arasındaki ilişkiye ait korelasyon değerleri

\begin{tabular}{lcccc} 
& & \multicolumn{3}{c}{ Çocuk İstismarı ve İhmali Bilgi Düzeyi } \\
\cline { 3 - 5 } & & Van YYÜ & Trakya Ünv. & Toplam \\
\hline \multirow{2}{*}{ Yükümlülük } & $\mathrm{r}$ & $.155^{* *}$ & -.075 & -.007 \\
& $\mathrm{P}$ & .010 & .252 & .878 \\
\multirow{2}{*}{ Kayg1 } & $\mathrm{r}$ & $.153^{*}$ & -.030 & -.028 \\
& $\mathrm{P}$ & .010 & .643 & .528
\end{tabular}




\begin{tabular}{llccc} 
& $\mathrm{r}$ & .090 & $-.128^{*}$ & -.058 \\
Değer & $\mathrm{P}$ & .136 & .049 & .192 \\
\multirow{2}{*}{ Güven } & $\mathrm{r}$ & -.005 & .101 & $-.169^{* *}$ \\
& $\mathrm{P}$ & .936 & .122 & .000 \\
\multirow{2}{*}{ Çocuğa Yönelik Cinsel İstismar Tutum } & $\mathrm{r}$ & $.139^{*}$ & -.020 & $-.116^{* *}$ \\
& $\mathrm{P}$ & .021 & .755 & .008 \\
\hline
\end{tabular}

${ }^{* *} \mathbf{p}<.01, * \mathbf{p}<.05$

Tablo 4'de yer alan karşılaştırmalı bulgulara göre, Van YYÜ'deki öğretmen adaylarının çocuk istismarı ve ihmaline ilişkin bilgi düzeyi puanları ile yükümlülük ( $\mathrm{r}=.155$; $p<.01)$ ve kaygı $(\mathrm{r}=.153 ; p<.05)$ alt boyutlarına ilişkin negatif tutum ile çocuğa yönelik cinsel istismar tutumu toplam puanı $(\mathrm{r}=.139 ; p<.05)$ arasında pozitif yönlü zayıf ilişki bulunmaktadır. Trakya Üniversitesi’ndeki öğretmen adaylarının ise, çocuk istismarı ve ihmaline ilişkin bilgi düzeyi puanları ile değer alt boyutuna ilişkin negatif tutum puanları arasında negatif yönlü zayıf ilişki bulunmaktadır ( $\mathrm{r}=-.128 ; p<.05)$. Tüm öğretmen adayları açısından bakıldığında, çocuk istismarı ve ihmali bilgi düzeyi puanları ile güven alt boyutuna ilişkin negatif tutum puanları $(\mathrm{r}=-.169 ; p<.01)$ ve çocuğa yönelik cinsel istismar tutumu toplam puanı $(\mathrm{r}=-.116 ; p<.01)$ arasında negatif yönlü zayıf ilişsi bulunmaktadır.

Alt Problem 3. Öğretmen adaylarının çocuk istismarı ve ihmali bilgi düzeyleri ile çocuğa yönelik cinsel istismar tutumları yaş, cinsiyet ve medeni durum değişkenlerine göre anlamlı bir farklılık göstermekte midir?

Yaş değişkenine göre öğretmen adaylarının çocuk istismarı ve ihmali bilgi düzeyleri ile çocuğa yönelik cinsel istismar tutum düzeylerinin karşılaştırılmasıyla ortaya çıkan ANOVA sonuçları Tablo 5’te verilmektedir.

Tablo 5. Öğretmen adaylarının çocuk ihmali ve çocuğa yönelik cinsel istismar bilgi düzeyleri ile çocuğa yönelik cinsel istismar tutum düzeylerinin yaş değişkenine göre karş1laştırılması

\begin{tabular}{|c|c|c|c|c|c|c|}
\hline Yaş & & $\mathbf{n}$ & $\overline{\mathbf{X}}$ & ss & $\mathbf{F}$ & $\mathbf{p}$ \\
\hline \multirow{3}{*}{$\begin{array}{l}\text { Çocuk İstismarı ve İhmali Bilgi } \\
\text { Düzeyi }\end{array}$} & $20-22$ & 165 & 3.16 & .68 & \multirow{3}{*}{18.427} & \multirow{3}{*}{$.000 *$} \\
\hline & $23-26$ & 250 & 2.78 & .65 & & \\
\hline & 27 ve üstü & 80 & 3.13 & .69 & & \\
\hline \multirow{3}{*}{ Yükümlülük } & $20-22$ & 165 & 1.25 & .39 & \multirow{3}{*}{1.204} & \multirow{3}{*}{.301} \\
\hline & $23-26$ & 250 & 1.19 & .39 & & \\
\hline & 27 ve üstü & 80 & 1.22 & .40 & & \\
\hline \multirow{3}{*}{ Kayg1 } & $20-22$ & 165 & 1.71 & .71 & \multirow{3}{*}{.168} & \multirow{3}{*}{.845} \\
\hline & $23-26$ & 250 & 1.68 & .82 & & \\
\hline & 27 ve üstü & 80 & 1.65 & .87 & & \\
\hline \multirow{2}{*}{ Değer } & $20-22$ & 165 & 1.24 & .40 & \multirow{2}{*}{1.264} & \multirow{2}{*}{.283} \\
\hline & $23-26$ & 250 & 1.21 & .37 & & \\
\hline
\end{tabular}




\begin{tabular}{llccccc} 
& 27 ve üstü & 80 & 1.29 & .51 & & \\
\hline \multirow{3}{*}{ Güven } & $20-22$ & 165 & 2.27 & .77 & & .060 \\
& $23-26$ & 250 & 2.43 & .81 & 2.832 & \\
& 27 ve üstü & 80 & 2.23 & .84 & & \\
\hline \multirow{2}{*}{ Çocuğa Yönelik Cinsel İstismar } & $20-22$ & 165 & 1.62 & .37 & & .863 \\
Tutumu & $23-26$ & 250 & 1.62 & .40 & .148 & .43 \\
& 27 ve üstü & 80 & 1.60 & & & \\
\hline
\end{tabular}

$* \mathbf{p}<.05$

Tablo 5'te görüldüğü üzere, öğretmen adaylarının çocuk istismarı ve ihmali bilgi düzeyleri yaşa göre anlamlı farklılık göstermektedir $\left[\mathrm{F}_{(2-514)}=18.427 ; \mathrm{p}<.05\right]$. Buna göre, en yüksek ortalamaya 20-22 yaş aralığındaki katılımcıların sahip olduğu $(\overline{\mathrm{X}}=3.16)$; en düşük ortalamaya ise 23-26 yaş aralı̆̆ında bulunanların sahip olduğu ( $\overline{\mathrm{X}}=2.78)$ görülmektedir. Çocuğa Yönelik Cinsel İstismar Tutum Ölçeği toplam puan ve alt boyutlarından elde edilen puanların yaşa göre anlamlı farklılık göstermediği bulunmuştur ( $\mathrm{p}>.05)$. Aynı zamanda, Van YYÜ ve Trakya Üniversitesi katılımcılarının kendi aralarındaki karşılaştırmasına göre; çocuk istismarı ve ihmali bilgi düzeyleri ile çocuğa yönelik cinsel istismarı bildirme tutumları arasında yaşa göre anlamlı farklılık görülmemiştir ( $\mathrm{p}>.05)$.

Cinsiyet değişkenine göre öğretmen adaylarının çocuk istismarı ve ihmali bilgi düzeyleri ile çocuğa yönelik cinsel istismar tutum düzeylerinin karşılaştırılmasıyla ortaya çıkan t testi sonuçları Tablo 6’da verilmektedir.

Tablo 6. Öğretmen adaylarının çocuk istismarı ve ihmali bilgi düzeyleri ile çocuğa yönelik cinsel istismar tutumlarının cinsiyete göre karșılaştırılması

\begin{tabular}{|c|c|c|c|c|c|c|}
\hline Cinsiyet & & $\mathbf{n}$ & $\overline{\mathbf{X}}$ & SS & $\mathbf{t}$ & $\mathbf{p}$ \\
\hline \multirow{2}{*}{ Çocuk İstismarı ve İhmali Bilgi Düzeyi } & Erkek & 343 & 3.09 & .70 & \multirow{2}{*}{5.466} & \multirow{2}{*}{$.000 *$} \\
\hline & Kadın & 169 & 2.77 & .61 & & \\
\hline \multirow{2}{*}{ Yükümlülük } & Erkek & 343 & 1.20 & .37 & \multirow{2}{*}{-1.258} & \multirow{2}{*}{.209} \\
\hline & Kadın & 169 & 1.25 & .43 & & \\
\hline \multirow{2}{*}{ Kayg1 } & Erkek & 343 & 1.64 & .76 & \multirow{2}{*}{-1.925} & \multirow{2}{*}{.055} \\
\hline & Kadın & 169 & 1.80 & .90 & & \\
\hline \multirow{2}{*}{ Değer } & Erkek & 343 & 1.23 & .41 & \multirow{2}{*}{-.464} & \multirow{2}{*}{.643} \\
\hline & Kadın & 169 & 1.25 & .44 & & \\
\hline \multirow{2}{*}{ Güven } & Erkek & 343 & 2.22 & .71 & \multirow{2}{*}{-4.410} & \multirow{2}{*}{$.000 *$} \\
\hline & Kadın & 169 & 2.57 & .91 & & \\
\hline \multirow{2}{*}{ Çocuğa Yönelik Cinsel İstismar Tutum } & Erkek & 343 & 1.57 & .37 & \multirow{2}{*}{-3.657} & \multirow{2}{*}{$.000 *$} \\
\hline & Kadın & 169 & 1.72 & .44 & & \\
\hline
\end{tabular}
$* \mathbf{p}<.05$

Tablo 6'ya göre, öğretmen adaylarının çocuk istismarı ve ihmali bilgi düzeyleri cinsiyete göre anlamlı olarak farklılaşmaktadır $\left(\mathrm{t}_{(513)}=5.466 ; p<.05\right)$. Buna göre, erkeklerin çocuk istismarı ve ihmali bilgi düzeyleri ( $\overline{\mathrm{X}}=3.09)$ kadınların ortalamalarından $(\overline{\mathrm{X}}=2.77)$ daha 
yüksektir. Öğretmen adaylarının çocuğa yönelik cinsel istismarı bildirmeye yönelik tutum düzeyleri toplam puan $\left(\mathrm{t}_{(513)}=-3.657 ; p<.05\right)$ ve güven alt boyutunda da $\left(\mathrm{t}_{(513)}=-4.410 ; p<.05\right)$ cinsiyete göre anlamlı farklılık saptanmıştır. Kadınların güven alt boyutuna ilişkin negatif tutum düzeyleri ( $\overline{\mathrm{X}}=2.57)$ ile çocuğa yönelik cinsel istismar negatif tutum düzeyi toplam puanının ( $\overline{\mathrm{X}}=1.72)$ daha yüksek olduğu bulunmuştur. Çocuğa yönelik cinsel istismar tutum ölçeğinin diğer alt boyutlarına göre anlamlı farklılık bulunmamaktadır ( $p>.05)$.

Van YYÜ’deki öğretmen adayları kendi aralarında cinsiyete göre karşılaştırıldığında çocuğa yönelik cinsel istismar tutum düzeylerinin toplam puan ve güven alt boyutunda cinsiyete göre anlamlı farklılık saptanmıştır $\left(\mathrm{t}_{(273)}=-3.023 ; p<.05\right)$. Kadınların güvene ilişkin negatif tutum düzeyi ( $\overline{\mathrm{X}}=2.66)$ ile çocuğa yönelik cinsel istismar negatif tutum düzeyi toplam puanı daha yüksektir $(\overline{\mathrm{X}}=1.76)$. Trakya Üniversitesi'ndeki öğretmen adaylarının ise sadece güven alt boyutuna ilişkin negatif tutum puanlarının cinsiyete göre değiştiği saptanmıştır $\left(\mathrm{t}_{(235)}=-2.051 ; p<.05\right) . \mathrm{Bu}$ boyutta da kadınların ortalamaları $(\overline{\mathrm{X}}=2.34)$ anlamlı olarak daha yüksek bulunmuştur.

Medeni duruma göre öğretmen adaylarının çocuk istismarı ve ihmali bilgi düzeyleri ile çocuğa yönelik cinsel istismar tutum düzeylerinin karşılaştırılmasıyla ortaya çıkan t testi sonuçları Tablo 7’de gösterilmiştir.

Tablo 7. Medeni duruma göre öğretmen adaylarının çocuk istismarı ve ihmali bilgi düzeyleri ile çocuğa yönelik cinsel istismar tutum düzeylerine ilișkin puanların karșılaștırılması

\begin{tabular}{|c|c|c|c|c|c|c|}
\hline Medeni durum & & $\mathbf{n}$ & $\overline{\mathbf{X}}$ & ss & $\mathbf{t}$ & $\mathbf{p}$ \\
\hline \multirow{2}{*}{ Çocuk İstismarı ve İhmali Bilgisi } & Evli & 218 & 3.48 & .52 & \multirow{2}{*}{19.054} & \multirow{2}{*}{$.000 *$} \\
\hline & Bekar & 287 & 2.58 & .53 & & \\
\hline \multirow{2}{*}{ Yükümlülük } & Evli & 218 & 1.19 & .35 & \multirow{2}{*}{-1.325} & \multirow{2}{*}{.186} \\
\hline & Bekar & 287 & 1.23 & .41 & & \\
\hline \multirow{2}{*}{ Kayg1 } & Evli & 218 & 1.63 & .70 & \multirow{2}{*}{-1.406} & \multirow{2}{*}{.160} \\
\hline & Bekar & 287 & 1.73 & .87 & & \\
\hline \multirow{2}{*}{ Değer } & Evli & 218 & 1.17 & .36 & \multirow{2}{*}{-2.917} & \multirow{2}{*}{$.004^{*}$} \\
\hline & Bekar & 287 & 1.28 & .45 & & \\
\hline \multirow{2}{*}{ Güven } & Evli & 218 & 2.24 & .77 & \multirow{2}{*}{-2.304} & \multirow{2}{*}{$.022^{*}$} \\
\hline & Bekar & 287 & 2.41 & .82 & & \\
\hline \multirow{2}{*}{ Çocuğa Yönelik Cinsel İstismar Tutum } & Evli & 218 & 1.56 & .36 & \multirow{2}{*}{-2.985} & \multirow{2}{*}{$.003^{*}$} \\
\hline & Bekar & 287 & 1.66 & .42 & & \\
\hline
\end{tabular}

${ }^{*} \mathbf{p}<.05 ;$ t testi

Tablo 7'ye göre, öğretmen adaylarının çocuk ihmali ve çocuğa yönelik cinsel istismara ilişkin bilgi düzeyleri medeni duruma göre değişmektedir $\left(\mathrm{t}_{(513)}=19.054 ; p<.05\right)$. 
Buna göre, evli olan öğretmen adaylarının çocuk istismarı ve ihmaline ilişkin bilgi düzeyleri ( $\overline{\mathrm{X}}=3.48)$ bekârlara göre $(\overline{\mathrm{X}}=2.58)$ daha yüksektir. Çocuğa Yönelik Cinsel İstismar Tutum Ölçeği toplam puanı $\left(\mathrm{t}_{(513)}=-2.985 ; p<.05\right)$ ile değer $\left(\mathrm{t}_{(513)}=-2.917 ; p<.05\right)$ ve güven $\left(\mathrm{t}_{(513)}=-\right.$ 2.304; $p<.05$ ) alt boyutlarının medeni duruma göre değiştiği saptanmıştır. Buna göre bekâr olan öğretmen adaylarının değere ilişkin negatif tutum düzeyi $(\overline{\mathrm{X}}=1.28)$, güvene ilişkin negatif tutum düzeyi ( $\overline{\mathrm{X}}=2.41)$ ile çocuğa yönelik cinsel istismara karşı toplam negatif tutum düzeyi ( $\overline{\mathrm{X}}=1.66)$ daha yüksek bulunmuştur. Medeni durum değişkenine göre, Van YYÜ ve Trakya Üniversitesi katılımcıları kendi aralarında çocuk istismarı ve ihmali bilgi düzeyleri ile çocuğa yönelik cinsel istismarı bildirme tutumları açısından yapılan karşılaştırmada anlamlı bir farklılık göstermedikleri bulunmuştur $(p>.05)$.

\section{Tartışma, Sonuç ve Öneriler}

Psikolojik, sosyolojik, tıbbi ve hukuki olarak çok yönlü etkileri bulunan ve beraberinde hem çocuk hem de toplum açısından farklı sonuçlar doğuran çocuk ihmali ve istismarı birçok disiplin açısından dikkatle değerlendirilmesi gereken bir konudur. Amerikan Psikoloji Birliği (2002) tarafından çocuk ihmal ve istismarı; ortaya koyduğu etkileri, kapsamı ve sıklığı açısından çocuğun başta psikolojik ve sosyal olarak sağlığını çok yönlü etkileyen önemli bir halk sağlığı sorunu olarak tanımlanmıştır. İhmal ve istismar konusunun çocuklarla çalışan profesyoneller tarafından tam olarak bilinmemesi, belirtilerin tanımlanamaması, bildirimde bulunulmaması, tanı konusunda yaşanan zorluklar, istismar ve ihmalin varlığının inkâr edilmesi ve gizlenmesi gibi faktörler konunun önemini gün geçtikçe daha da arttırmaktadir.

Öğretmen adaylarının çocuk istismarı ve ihmaline ilişkin bilgi düzeyleri ile çocuğa yönelik cinsel istismarı bildirme tutumlarının incelendiği bu araştırmada, toplam 515 öğretmen adayının \%87.5'inin çocuk ihmal ve istismarı konusunda herhangi bir eğitim almadığı, \%51.9'unun ise bu konudaki bilgi düzeyini "fazla" olarak değerlendirdikleri görülmüştür. Alan yazın incelendiğinde, bazı çalışmalarda benzer bulguların elde edildiği görülmektedir. Yaşar ve arkadaşları (2018), öğretmenlerin \%73.3'ünün; Yetiş ve Ziyalar (2018) \%59.7'sinin ve Pala (2011) ise öğretmen adaylarının \%91,2'sinin çocuk istismarı ve ihmali konusunda herhangi bir eğitim almadıklarını belirlemiştir.

Öğretmenlerin çocuk istismar ve ihmaline ilişkin belirtileri değerlendirebilmeleri, şüpheli durumlarda nasıl bir yol izlemeleri ve hangi birimlere bildirimde bulunmaları 
gerektiği konusunda bilgi sahibi olmaları çok önemlidir. Bu nedenle öğretmenlerin istismar ve ihmal durumunda ortaya çıkabilecek hukuki, mesleki ve sosyal süreçlerin yönetiminde gerekli olan bilgi ve yeterliğe sahip olabilmeleri özellikle lisans eğitiminde düzenli ve planlı bir biçimde çocuk ihmali ve istismarı ile ilgili eğitim almaları ile mümkündür (Farrell ve Walsh, 2010). Bu açıdan bakıldığında; lisans eğitimi, öğretmen adaylarının çocuk ihmali ve istismarı hakkında bilinçlenecekleri uygun bir zaman dilimi olarak görülmektedir. Ancak yapılan çalışmalar incelendiğinde (Çatık ve Çam, 2006; Dereobalı, Çırak Karadağ ve Sönmez, 2013; Dilsiz ve Mağden, 2015; Özyürek ve Çetin, 2018; Savi Çakar ve Yazıcı Okuyan, 2017); çoğunlukla bu yönde ya hiç eğitim alınmadığı ya da alındıysa düzey olarak yetersiz olduğu değerlendirmiştir. Yine öğretmen adaylarının çocuk ihmal ve istismarına ilişkin mezuniyet öncesi uygulamalı eğitim almalarının yeterlikleri açısından önemli olduğu (Goldman ve Bradley, 2011), çocuk koruma ve yasal düzenlemeler konusunda zorunlu bir dersin olması (Goldman ve Grimbeek, 2011) gerektiği vurgulanmıştır. Yaşar, Şenol ve Akyol (2015) öğretmen adaylarıyla yaptıkları çalışmada, \%78.6'sının “Çocuk Koruma Kanunu” hakkında bilgilerinin olmadığı görülmüştür. Ancak yapılan çalışmalar, çocuk koruma eğitim programını alan öğretmen adaylarının risk etmenleri, uygulama süreçleri ve yasal düzenlemelerle ilgili bilgi düzeylerinin arttı̆̆ını (McKee ve Dillenburger, 2012); çocuk ihmali ve istismarı konusunda eğitim alanların, almayanlara oranla ihmal ve istismar belirtilerini tanıma ve yorumlamada mesleki yeterliliklerine daha fazla güvendiklerini (Yetiş ve Ziyalar, 2018) ortaya koymuştur. Görüldüğü gibi öğretmenlerin çocuk ihmali ve istismarına yönelik eğitim alma durumu, çocuk ihmal ve istismarını belirlemede önemli bir değişken olarak (Sarıbaş, 2013; Tugay, 2008) karşımıza çıkmaktadır.

Araştırmanın bir bulgusu da, öğretmen adaylarının çocuk ihmali, cinsel istismar belirtileri ve istismar ve ihmalde risk tanıma ile ilgili bilgi düzeylerinin orta düzeyde olduğudur. Benzer olarak; Çopur, Balcı ve Günay’ın (2019) araştırmalarında sağlık meslek lisesinde çalışan öğretmenlerin çocuk istismarı ve ihmali ile ilgili yeterli bilgiye sahip olmadıkları bulunmuştur. Pala'nın (2011) çalışmasında, öğretmen adaylarının istismar türlerinden en çok cinsel istismarı belirlemede kendilerini yeterli bulmadıkları ve bu konuda kendilerini çok hazırlıksız değerlendirdikleri görülmüştür. Profesyonel kişilerin ve eğitimcilerin çocuk istismarı ve ihmali ile ilgili önemli ipuçları olarak sayılacak davranışsal ve fiziksel belirtileri tanımaları ve bu tip durumlarla karşılaştıklarında bildirimde bulunma sorumluluklarının farkında olmaları önemlidir (Ersoy ve Özkan, 2017). Yapılan çok sayıda çalışma sonuçları (Farrell ve Walsh, 2010; Kenny, 2004; Tugay, 2008), öğretmenlerin çocuk 
istismarı belirtilerini tanıma ve hangi birimlere bildirimde bulunmaları gerektiği ile ilgili yeterli oranda bilgi düzeyine sahip olmadıklarını ortaya koymuştur. Üniversiteler arası karşılaştırma yapıldığında ise; çocuk ihmali ile ilgili maddelere Trakya Üniversitesi'ndeki öğretmen adaylarının Van YYÜ öğretmen adaylarına göre daha yüksek ortalamalarda katılım gösterdikleri görülmüştür. Aynı maddeye katılım düzeyinin bir üniversitede en yüksek iken diğerinde en düşük olması araştırmanın ilginç bir bulgusudur. $\mathrm{Bu}$ bulgu, çocuk istismarı ve ihmali ile bilginin elde edilmesinde sistematik bir yöntemin olmadığg, gelişigüzel kazanıldığg, bilgi somut ve net iken bilinenin farklı düzeylerde olduğu şeklinde yorumlanabilir. Öğretmenlerin bilginin kaynağı konumunda olan profesyonel meslek gruplarından birisi olduğu düşünülürse bu konudaki dengesizlik ve yetersizliklerin giderilmesi önemlidir. Nitekim, çocuk istismarı ve ihmali ile ilgili yeterli düzeyde bilgi sahibi olunmaması ve bu eksikliği gidermeye yönelik eğitim programlarının yetersiz olması da bu durumu etkilemektedir (Keser, Odabaş ve Elibüyük, 2010).

Öğretmen adaylarının, çocuk istismar ve ihmaline ilişkin bilgi düzeyleri \% 60 iken çocuğa yönelik cinsel istismarını bildirmeye ilişkin tutum düzeyleri \% 32'dir. Bu sonuç, öğretmen adaylarının her ne kadar çocuk istismarı ve ihmali konusunda bilgileri olsa da cinsel istismarı bildirmeye yönelik tutumlarının düşük düzeyde olduğu şeklinde yorumlanabilir. Çocuk ihmali ve istismarını bildirmekle sorumlu bir meslek grubu olan öğretmenlerin tutumları çok sayıda araştırmaya konu olmuştur. İstismara uğrayan çocukların belirlenmesi, ilgili birimlere bildirilmesi, yönlendirilmesi ve istismarın önlenmesi noktasında öğretmenlerin önemli sorumlulukları bulunmaktadır (Fayez, Takash ve Al- Zboon, 2014; Kenny, 2001; Walsh, Bridgstock, Farrella, Rassafianib, Schweitzer, 2008). Yap1lan bir çalışmada, öğretmen adaylarının \%95.4'ünün hukuksal olarak, \%89,8'sinin Milli Eğitim kanunlarına göre, \%99’unun ise ahlaki olarak çocuk istismar ve ihmalini bildirme yönünde yükümlülükleri olduğunu bildirilmiştir (Yaşar, Şenol ve Akyol, 2015). Ancak edinilen bilgiler sonucunda şüpheli olduğu düşünülen çocuk istismarı vakası durumunda bildirim yapma konusunda öğretmenlerin yasal sorumluluk teşkil etmesine rağmen bildirim yapmanın çocuk açısından doğuracağı sonuçlar nedeniyle bildirim yapmaktan çekindikleri bilinmektedir (Beck, Ogloff ve Corbishley,1994). Daha önce rapor edildiği gibi bu durumun günümüzde de devam ettiği görülmektedir. Yine öğretmenlerin cinsel istismara uğrayan çocuğu fark etme ve bildirimde takip etmeleri gereken süreç konusunda yeterli düzeyde bilgi sahibi olmadıkları özellikle de ensest durumla karşılaştıklarında mücadele etmeyi göze alamadıkları belirlenmiştir (Tekin ve Özgül, 2015). Abraham, Casey ve Daro (1992) 
tarafindan yapılan çalışmada, öğretmenlerin bildirimde bulunmalarını güçleştiren nedenler arasında ihmal ve istismar durumunun tespit ve müdahalesi konusunda yeterli düzeyde bilgi sahibi olmama ile gerçek olmayan iddia ve bildirimlerin sonuçlarından kaygı duyma olarak sıralanmıştır. Ayrıca, öğretmenler hem dikkate alınmayacakları hem de aldıkları eğitimin yetersiz olduğu düşüncesiyle bildirimde bulunmadıklarını ifade etmişlerdir (Yaşar ve ark., 2018). Aynı zamanda, öğretmenlerin istismarı bildirme süreçleri üzerinde istismar türünün önemli bir etkisi olduğu belirtilmiştir (Walsh, Bridgstock, Farrella, Rassafianib ve Schweitzer, 2008). Bu nedenle cinsel istismarın bildirimi konusunda daha fazla kaygı duyulduğu bilinmektedir. Öğretmenlerin bildirimde bulunmaya yönelik negatif tutumlarının; bildirimde bulunmaları halinde yöneticileri tarafından desteklenmediklerini düşünmeleri (Kenny, 2001), delil yetersizliği, çocukların daha fazla zarar görecekleri endişesi ve çocukları korumayla yükümlü kurumlara olan güvensizlik (Beck, Ogloff ve Corbishley,1994), öğretmen adaylarının istismarı ortaya çıkarma ve bildirme konusunda yükümlülüğün özellikle okul yöneticilerine ya da psikolojik danışmanlara ait olduğunu düşünmeleri (Fayez, Takash ve Al- Zboon, 2014) ile ilgili olduğu belirtilmektedir. Yapılan başka bir çalışmada ise (Yetiş ve Ziyalar, 2018), öğretmenlerin zorunlu bildirime karşı olumlu bir tutuma sahip oldukları, ancak bilgi eksikliği yaşadıkları, bildirim süreci ve sistemini değerlendirmede kararsız kaldıkları ve bildirim sürecine ilişkin yol haritalarının net olmadığı sonucuna varılmıştır. Ancak belirtildiği gibi (Goldman ve Grimbeek, 2008), öğretmenlerin cinsel istismarı bildirmeye yönelik yükümlülüklerinin bilincinde olmaları, onların cinsel istismar belirtilerini tanıma ve değerlendirme konusunda farkındalık kazanmalarını sağlayacaktır.

Öğretmen adaylarının çocuk istismarı ve ihmali bilgi düzeyleri ile cinsel istismara yönelik tutumları arasındaki ilişkiye ait karşılaştırmalı bulgular incelendiğinde, Van YYÜ’deki öğretmen adaylarının bilgi düzeyleri arttıkça alt boyutlarda çocuğa yönelik cinsel istismarı bildirmeye ilişkin kaygılarının da arttığı ve bildirimde bulunmaya karşı yükümlülük boyutunda negatif tutumlarının da arttığı görülmüştür. Bu sonuç, Van YYÜ’deki öğretmen adaylarının çocuğa yönelik cinsel istismarı bildirmeye ilişkin yükümlülük alt boyutunda daha fazla negatif bir tutuma sahip olduklarını bir diğer ifade ile yükümlülük istemediklerini göstermektedir. Aynı zamanda kaygılarının yüksek olduğu dolayısıyla buna bağlı olarak çocuğa yönelik cinsel istismarı bildirmeye yönelik tutumları da düşüktür. Öğretmenlerin çocuk ihmal ve istismarı konusunda sorumluluk duyguları arttıkça daha fazla bildirimde bulundukları; özgüven eksikliği ve şüpheli durumların bildirilmesi konusundaki kaygıları arttığında ise daha az bildirimde bulundukları sonucuna ulaşılmıştır (Kenny, 2001). Yetiş ve 
Ziyalar (2018), çalışmalarında çocuk istismarı ve ihmali konusunda eğitim alan ve almayan katılımcıların bildirim sonrası süreçte ailenin ya da toplumun bildirim yapan kişiye karşı öfkeli ve saldırgan tavırlar sergilemesinden dolayı kaygı duyduklarını ifade etmişlerdir. Ancak, daha önce çocuk istismarı ve ihmali konulu eğitim alan katılımcıların, bu ifadeye katılma oranının, daha önce eğitim almayan katılımcılardan anlamlı düzeyde daha yüksek olduğu bulgulanmıştır. Aynı zamanda, çocuk istismarı ve ihmali hakkında eğitimi olan öğretmen adaylarının da istismar durumları ile mücadele edebilmenin güç olduğunu, hangi yollarla üstesinden gelineceği noktasında kaygılı oldukları belirtilmiştir (Baginsky ve Macpherson, 2005). Buradan da görüleceği gibi aslında farkındalık arttıkça bildirim sonrasında karşılaşılabilecek riskleri algılamanın da arttı̆̆ı bunun da cinsel istismarı bildirmeye yönelik olumsuz tutumları arttırdığı söylenebilir. Trakya Üniversitesi’ndeki öğretmen adaylarının ise farkındalığı arttıkça çocuğa yönelik cinsel istismarın bildirilmesine yüklediği değer de artmaktadır. Bu sonuç bilgi düzeyleri arttıkça bildirimde bulunmanın gerekliliğine daha fazla inandıklarını ortaya koymaktadır. Tüm öğretmen adaylarının bilgi düzeyi ile çocuğa yönelik cinsel istismarı bildirilmeye yönelik tutumları arasındaki ilişkiye bakıldığında bilgi düzeyi arttıkça güven artmakta ve çocuğa yönelik cinsel istismarı bildirmeye yönelik negatif tutum azalmaktadır. Yapılan çalışmalar, çocuk istismarı ile ilgili daha önce eğitim gören öğretmenlerin eğitimi olmayan öğretmenlere oranla çocuk istismarını daha fazla bildirdiklerini ortaya koymuştur (Kenny, 2004; Webster, O’Toole, O’Toole ve Lucal, 2005; Goebbels, Nicholson, Walsh ve De Vries, 2008).

Yaş değişkenine göre öğretmen adaylarının cinsel istismar ve ihmaline ilişkin bilgi düzeylerine bakıldığında, 20-22 yaş aralığındaki öğretmen adaylarının en yüksek ortalamaya; 23-26 yaşındakilerin ise en düşük ortalamaya sahip olduğu görülmüştür. Öğretmen adaylarının cinsel istismarı bildirmeye yönelik tutumlarının ise yaşa göre farklılaşmadığı saptanmıştır. Yapılan çalışmada (Yaşar ve ark., 2018), öğretmenlerin yaşları arttıkça çocuğa yönelik cinsel istismar tutumlarının yükseldiği görülmüştür. Okul öncesi öğretmen adaylarının çocuk istismarına ilişkin düşüncelerinin ve tutumlarının belirlemesi amacıyla yapılan başka bir çalışmada (Bishop, Lunn ve Johnson, 2002), son sınıf öğretmen adaylarının mesleki anlamda daha büyük sorumluluk taşıdıkları belirtilmiştir. Yapılan diğer çalışmalarda da (Türk, 2010; Yaşar, Şenol ve Akyol, 2015), üst sınıflarda olan öğretmen adaylarının çocuk istismarı hakkındaki farkındalık düzeylerinin alt sınıflarda olan öğretmen adaylarına oranla daha yüksek çıktığı sonucuna ulaşılmıştır. Bu çalışmada 20-22 yaş aralığındaki öğretmen adaylarının çoğunlukla son sınıf oldukları düşünüldüğünde, cinsel istismar ve ihmaline ilişkin 
bilgi düzeylerinin daha yüksek düzeyde olması, alan derslerini almış olmaları, öğretmenlik mesleğinin sosyal işlevi konusunda farkındalık kazanmış olmalarıyla ilgili olabilir. Ancak öğretmen adaylarının bilgi düzeyleri arasında farklılık olsa da cinsel istismarı bildirmeye yönelik tutumlarında anlamlı farklılık görülmemesi cinsel istismarın bildiriminde yaş dışında başka faktörlerin etkili olduğu söylenebilir.

Öğretmen adaylarının çocuk istismarı ve ihmali bilgi düzeyleri cinsiyet değişkeni açısından değerlendirildiğinde, erkeklerin ortalamaları kadınlara göre daha yüksektir. Ancak bu bulgunun aksine yapılan çalışmalar, cinsiyet açısından farklılık olmadığını ortaya koymuştur. Örneğin, Sağır (2013) tarafından yapılan çalışmada, öğretmenlerin çocuk ihmali ve istismarı konusundaki farkındalık düzeylerinin cinsiyete göre anlamlı bir fark yaratmadığı; yine cinsel istismarın davranışsal belirtilerini tanıma açısından cinsiyete göre farklılaşma olmadığı (Sarıbaş, 2013) bulunmuştur. Cinsel istismarı bildirmeye yönelik tutum açısından bakıldığında; kadınların çocuğa yönelik cinsel istismar tutum ölçeğinin toplam puan ve güven alt boyutuna ilişkin negatif tutum puanları erkeklerden daha yüksek bulunmuştur. Kadınların çocuk istismarını bildirme konusunda daha güvensiz ve genel olarak çocuğa yönelik cinsel istismarı bildirmeye konusunda daha olumsuz tutum sergiledikleri başka bir ifade ile bildirimde bulunmak istemedikleri söylenebilir. Bu yönde yapılan çalışmalara bakıldığında cinsiyete göre farklı sonuçlar elde edildiği görülmektedir. Yapılan bazı çalışmalarda (Yaşar, Şenol ve Akyol, 2015; Kenny, 2001; Pala, 2011) cinsel istismarı bildirmede cinsiyete göre anlamlı farklılık olmadığı; her iki cinsiyetin çocuğa yönelik cinsel istismar tutumlarında benzer özellikler sergiledikleri belirtilmiştir. Diğer bazı çalışmalarda (Yaşar ve ark., 2018; O'Toole, Webster, O'Toole ve Lucal, 1999) ise öğretmenlerin çocuğa yönelik cinsel istismar tutumlarının cinsiyete göre farklılaştığı, buna göre kadın öğretmenlerin çocuk ihmal ve istismarını bildirim oranlarının erkek öğretmenlere göre anlamlı derecede daha yüksek olduğu bulunmuştur. Bu sonuç, araştırmacılar tarafından annelerin çocuklarıyla kurduğu bağ ve kadınların cinsel istismara daha fazla maruz kalmaları nedeniyle duyarlıklarının arttığı şeklinde yorumlanmıştır (Yaşar ve ark., 2018; Hornor, 2010). Üniversite bazında öğretmen adayları cinsiyetlerine göre karşılaştırıldığında, Van YYÜ'deki kadın öğretmen adaylarının güvene ilişkin negatif tutum düzeyi ile çocuğa yönelik cinsel istismar negatif tutum düzeyi toplam puanının daha yüksek olduğu bulunmuştur. Benzer olarak Trakya Üniversitesi’ndeki kadın öğretmen adaylarının da güven alt boyutuna ilişkin negatif tutum puanlarının daha yüksek olduğu görülmüştür. Bu sonuçlardan yola çıkarak kadınların bildirim yapmaya karşı daha güvensiz olduğu söylenebilir. 
Sonuç olarak; öğretmen adaylarının çocuk ihmali ve istismarına ilişkin bilgi sahibi olması, mağdur çocukların fark edilmesi, mağdur çocuğa yaklaşım, yasal bildirim yükümlülügünün yerine getirilmesi açısından oldukça büyük önem taşımaktadır. Okullarda öğretmenlerin çocuk ihmali ve istismarına karşı koruyucu ve önleyici çalışmalar yürütebilmeleri için de bu konuda donanımlı olmaları gerekmektedir. Bu nedenle araştırma sonuçlarına dayanarak, eğitim fakültelerinin programlarında meslek bilgisi kodlu eğitim dersleri arasında çocuk ihmali ve istismarının zorunlu ders olarak yer alması, formasyon programlarında da bu dersin yer alması gerektiği önerilmektedir. Öğretmenlerin bildirim yapmaya ilişkin yasal yükümlülüklerini yerine getirmeye engel teşkil edebilecek güven ve kaygı teşkil eden sorunların belirlenip çözümlenmesinin de bildirim yapmaya yönelik olumlu tutum geliştirilmesine neden olacağı düşünülmektedir. Bu araştırma, Trakya Üniversitesi ve Van Yüzüncüyıl Eğitim Fakültelerinde öğrenim gören pedagojik formasyon öğrencileri ile sınırlı olup gelecek araştırmalarda farklı örneklem grupları üzerinde de inceleme yapılması önerilmektedir.

\section{Makalenin Bilimdeki Konumu}

Eğitim Bilimleri Bölümü/ Rehberlik ve Psikolojik Danışma Anabilim Dalı

\section{Makalenin Bilimdeki Özgünlüğü}

Son yıllarda cinsel istismara uğramış çocuk ve gençlerle ilgili vakalar gerek ülkemizde gerekse dünyada gittikçe daha fazla görülmeye başlamıştır. Yazılı ve görsel basında yer alan haberlerin, sivil toplum örgütlerinin yaptıkları çalışmaların toplumda bu konudaki hassasiyeti $\operatorname{artırdığı~ve~tıbbi,~hukuki,~eğitim~ve~sosyal~hizmet~boyutlarında~farkındalık~oluşturduğu~}$ söylenebilir. Özellikle cinsel istismarın ortaya çıkmasında öğretmenlerin önemli bir rol oynadığı görülmektedir. Bu nedenle cinsel istismarın önlenmesi konusunda çok önemli bir role sahip olan öğretmenlerin farkındalıklarının artırılması ile cinsel istismarın tespit edilmesi, önleyici ve müdahale çalışmalarına katkı sağlayacağı düşünülmektedir.

\section{Kaynaklar}

Abrahams, N., Casey, K., \& Daro, D. (1992). Teachers' knowledge, attitudes, and beliefs about child abuse and its prevention. Child Abuse \& Neglect, 16(2), 229-238.

Akın, A., Aşut, S., Demirci, İ., Akbaş, Ş. Z., Güler, H., Demir, O., \& Kaymaz, B. (2013). Çocuğa yönelik cinsel istismar tutum ölçeği Türkçe formu'nun geçerlik ve 
güvenirliği. VI. Ulusal Lisansüstü Eğitim Sempozyumu Bildiriler Kitabı II, Sakarya, 11-14.

Aksel, Ş., \& Yılmaz-Irmak, T. (2015). Çocuk cinsel istismarı konusunda öğretmenlerin bilgi ve deneyimleri. Ege Eğitim Dergisi, 2(16), 373-391.

Aktepe, E. (2009). Çocukluk çağı cinsel istismarı. Psikiyatride Güncel Yaklaşımlar,1, 95-119.

American Psychological Association (APA). (2002). Violence and the family: Report of the American Psychological Association Presidential Task Force on violence and the family. Washington, DC.

Asuma \& İmdat. (2018). Çocuk İstismarına Yönelik Rapor-2. Erişildiği site: http://imdat.org/wp-content/uploads/2018/04/Rapor-Çocuk-İsmarı-tam v2_cleancopy.pdf Erişim tarihi:18.09.2019.

Aydemir, İ., \& Yurtkulu, F. (2012). Çocuğa yönelik cinsel istismarla mücadelede: Çocuk İzlem Merkezi. Ankara Sağlık Bilimleri Dergisi, 1(2), 153-165.

Baginsky, M., \& Macpherson, P. (2005). Training teachers to safeguard children: Developing a consistent approach. Child Abuse Review, 14(5), 317-330.

Beck, K. A., Ogloff, J. R., \& Corbishley, A. (1994). Knowledge, compliance, and attitudes of teachers toward mandatory child abuse reporting in British Columbia. Canadian Journal of Education/Revue canadienne de l'education, 15-29.

Bishop, A., Lunn, P., \& Johnson, K. (2002). 'I would just like to run away and hide, but I won't!' exploring attitudes and perceptions on child protection issues with early years teacher trainees on the threshold of their careers. Westminster Studies in Education, 25(2), 187-199.

Burç, A., \& Güdücü, T.F. (2015). Hemşirelerin çocuk istismarı ve ihmalinin belirti ve risklerini tanılama düzeyleri. Acıbadem Üniversitesi Sağlık Bilimleri Dergisi, 6(3): 144151.

Choo, W. Y., Walsh, K., Chinna, K., \& Tey, N. P. (2013). Teacher reporting attitudes scale (TRAS) confirmatory and exploratory factor analyses with a Malaysian sample. Journal of Interpersonal Violence, 28(2), 231-253.

Çatık, A.E., \& Çam, O. (2006). Hemşire ve ebelerin çocuk istismarı ve ihmalinin belirti ve risklerini tanıma düzeylerinin saptanması. Ege Üniversitesi Hemşirelik Yüksek Okulu Dergisi, 22(2), 103-119.

Çeçen, A. R. (2007). Çocuk cinsel istismarı: Sıklı̆̆ı, etkileri ve okul temelli önleme yolları. Uluslararası Insan Bilimleri Dergisi, 1, 1-17. 
Çopur, A, Balc1, E., \& Günay, O. (2019). Sağlık meslek lisesinde görev yapan öğretmenlerin çocuk ihmal ve istismarı konusundaki bilgi düzeylerinin belirlenmesi. Uluslararası Sosyal Araştırmalar Dergisi, 12(63), 808-813.

Dağlı, E.T., \& İnanıcı, M.A. (2011). Hastane temelli çocuk koruma merkezleri için başvuru kitabı ihmal ve istismara uğrayan çocuğa bütüncül yaklaşım. 1.Bask1 Ankara: UNICEF

Demir, H. (2012). Edirne ili aile să̆lı̆̆l merkezlerinde görevli hekimlerin çocuk istismarl ve ihmali hakkında bilgi, farkındalık ve tutumlarının belirlenmesi. Halk Sağlı̆̆ı Uzmanlık Tezi, Trakya Üniversitesi, Edirne

Dereobalı, N., Karadağ, S. Ç., \& Sönmez, S. (2013). Okulöncesi eğitim öğretmenlerinin çocuk istismari ihmali şiddet ve eğitimcilerin rolü konusundaki görüşleri. Ege Eğitim Dergisi, 14(1), 50-66.

Dilsiz, H., \& Mağden, D. (2015). Öğretmenlerin çocuk istismar ve ihmali konusunda bilgi ve risk tanıma düzeylerinin tespit edilmesi. Hacettepe University Faculty of Health Sciences Journal, 2.

Dönmez, Y.E., Soylu, N., Özcan, Ö.Ö., Yüksel, T., Demir, A.Ç., Bayhan, P.Ç., \& Miniksar, D.Y. (2014). Cinsel istismar mağduru çocuk ve ergen olgularımızın sosyodemografik ve klinik özellikleri. Journal Of Turgut Özal Medical Center, 21(1), 44-48.

Erdoğan, Y., \& Aslan, D. (2020). Okul öncesi öğretmenlerinin çocuk istismarı ve ihmaline yönelik algıları. Mersin Üniversitesi Ĕ̌itim Fakültesi Dergisi, 16(1), 104-132.

Eren-Gümüş, A. (2017). Çocuk cinsel istismarı şüphesinin bildirimi öncesinde çocukla yapılacak ilk görüşme. Klinik Psikiyatri, 20, 45-58.

Erermiş, S. (2001). Çocuk ihmali nedir? İzmir Atatürk Hastanesi Tıp Dergisi, 39(2), 710

Erol, D. (2007). Okulöncesi eğitim kurumlarında görev yapan öğretmenlerin, çocuklardaki fiziksel istismar belirtilerine ilişkin farkındalıkları (Eskişehir İl Örneği). Yüksek Lisans Tezi, Anadolu Üniversitesi, Eskişehir.

Ersoy, Ö. A., \& Özkan, H. K. (2017). Okul öncesi dönem çocuklarının cinsel istismara ilişkin bilgilerinin incelenmesi: Nitel bir bakış. Cumhuriyet International Journal of Education, 6(1), 123-139.

Farrell, A., \& Walsh, K. (2010). Working together for Toby: Early childhood student teachers engaging in collaborative problem-based learning around child abuse and neglect. Australasian Journal of Early Childhood, 35(4), 53-62. 
Fayez, M., Takash, M.H., \& Al-Zboon, K.E. (2014). Combating violence against children: Jordanian pre-service early childhood teachers' perceptions towards child abuse and neglect. Early Child Development and Care, 184(9-10), 1485-1498

Goebbels, A.F.G., Nicholson, J.M., Walsh, K., \& De Vries, H. (2008). Teachers’ reporting of suspected child abuse and neglect: Behavior and determinants. Health Education Research, 23(6), 941-951.

Goldman, J. D. G., \& Padayachi, U. K. (2005). Child sexual abuse reporting behaviour by school counsellors and their need for further education. Health Education Journal, 64, 302-322.

Goldman, D.G.J., \& Grimbeek, P. (2008). Student teachers' understanding of policy behavioural directives concerning the reporting of child sexual abuse: Findings from one Australian state. Educational Research, 50(3), 291-305.

Goldman, D.G.J., \& Grimbeek, P. (2011). Sources of knowledge of departmental policy on child sexual abuse and mandatory reporting identified by primary school student teachers. Educational Review, 63(1), 1-18.

Goldman, J.D., \& Bradley, G.L. (2011). Assessing primary school student-teachers’ pedagogic implementations in child sexual abuse protection education. European Journal of Psychology of Education, 26(4), 479-493.

Gümüş, A. E. (2017). Çocuk cinsel istismarı şüphesinin bildirimi öncesinde çocukla yapılacak ilk görüşme. Klinik Psikiyatri Dergisi, 20(1), 45-58.

Gündüz, H. Ç., \& Yıldız, A. D. (2016). Cinsel İstismarın Önlenmesinde Cinsel Eğitimin Önemi.

Erişim adresi: https://www.researchgate.net/publication/323657089_Cinsel_Istismarin_ Onlenmesinde_Cinsel_Egitiminin_Onemi.

Hornor, G. (2010). Child sexual abuse: Consequences and implications. Journal of Pediatric Health Care, 24(6), 358-364.

İbiloğlu, A.O., Atlı, A., Oto, R., \& Özkan, M. (2018). Çocukluk çağı cinsel istismar ve ensest olgularına çok yönlü bir bakış. Psikiyatride Güncel Yaklaşımlar, 10(1),84-98.

İşeri, E. (2008). Cinsel istismar. İçinde F.Ç. Çetin, B. Pehlivantürk, F.Ünal ve ark.(Ed.), Çocuk ve ergen psikiyatrisi temel kitabı (ss:470-477). Ankara: Hekimler Yayın Birliği.

Karasar, N. (2010). Bilimsel araştırma yöntemi (21. baskı).Ankara: Nobel Yayın Dağıtım

Kenny, M. C. (2004). Teachers' attitudes toward and knowledge of child maltreatment. Child Abuse \& Neglect, 28(12), 1311-1319. 
Kenny, M.C. (2001). Child abuse reporting: Teachers’ perceived deterrents. Child Abuse \& Neglect, 25(1), 81-92.

Keser, N., Odabaş, E., \& Elibüyük, S. (2010). Ana-babaların çocuk istismarı ve ihmali konusundaki bilgi düzeylerinin incelenmesi. Türkiye Çocuk Hastalıkları Dergisi, 4(3), 150-157.

Koçtürk, N., \& Bilge, F. (2017). Social support of adolescent survivors of childhood sexual abuse and sexual revictimization in Turkey. Journal of Child Sexual Abuse, 27(1), 3852.

McKee, B.E., \& Dillenburger, K. (2012). Effectiveness of child protection training for preservice early childhood educators. International Journal of Educational Research, 53, 348-359.

O’Toole, R., Webster, S. W., O’Toole, A. W., \& Lucal, B. (1999). Teachers’ recognition and reporting of child abuse: A factorial survey. Child Abuse \& Neglect, 23(11), 10831101.

Ovayolu, N., Uçan, Ö., \&, Serindağ, S. (2007). Çocuklarda cinsel istismar ve etkileri. Fırat Sağllk Hizmetleri Dergisi, 2(4), 13-22.

Özyürek, A., \& Çetin, A. (2018). Aile hekimi ve öğretmenlerin çocuk ihmal ve istismarı konusundaki görüş ve tutumları. Insan ve Toplum Bilimleri Araştırmaları Dergisi, 7(1), 436-453.

Pala, B. (2011). Geleceğin öğretmenlerinin çocuk istismarı ve ihmali konusunda bilgi ve farkındalık düzeyleri. Aile Hekimliği Anabilim Dalı Tıpta Uzmanlık Tezi, Osmangazi Üniversitesi Tıp Fakültesi, Eskişehir.

Polat, O. (2001). Çocuk ve şiddet. İstanbul: Der Yayınları.

Sağır, M., \& Gözler, A. (2013). Sınıf öğretmenlerinin çocuk istismarı ve ihmaline yönelik görüşleri ve farkındalık düzeyleri. Türkiye Sosyal Politika ve Çalışma Hayatı Araştırmaları Dergisi, 3(5), 67-102.

Sarıbaş, K.A. (2013). Okul öncesi öğretmenlerinin çocuk istismarına yönelik farkındalıklarının belirlenmesi. Yüksek Lisans Tezi, Eğitim Bilimleri Enstitüsü, Çanakkale Üniversitesi, Çanakkale.

Savi Çakar, F., \& Yazıcı Okuyan, H. (2017). Öğretmen adaylarının çocuk istismarı ve ihmaline ilişkin görüşleri. Mehmet Akif Ersoy Üniversitesi Eğitim Fakültesi Dergisi, 44, 250275. 
Simonelli, A. (2013). Posttraumatic stress disorder in early childhood: classification and diagnostic issues. European Journal of Psychotraumatol. 4, doi: 10.3402/ejpt.v4i0.21357

Taner, Y., \& Gökler, B.(2004). Çocuk istismar ve ihmali: Psikiyatrik yönleri. Hacettepe Tıp Dergisi, 35,82-86.

Taner, H.A., Çetin, F.H., Işık, Y., \& İşeri, E.(2015) Cinsel istismara uğrayan çocuk ve ergenlerde psikopatoloji ve ilişkili risk etkenleri. Anadolu Psikiyatri Dergisi, 16,294300.

Tekin, U., \& Özgül, D. (2015). Çocuğun cinsel istismar uğradığı durumlarda öğretmen ve okul yöneticilerinin tutum ve davranışları. İstanbul Aydın Üniversitesi Ĕgitim Fakültesi Dergisi, 1(1), 1-29.

Toros, K., \& Tirik, R. (2016). Preschool teachers' perceptions about and experience with child abuse and neglect. Early Childhood Education Journal, 44(1), 21-30.

Tugay, D. (2008). Öğretmenlerin çocuk istismarı ve ihmaline yönelik farkındalık düzeyleri. Yüksek Lisans Tezi, Sağlık Bilimleri Enstitüsü, Marmara Üniversitesi, İstanbul.

Türk Ceza Kanunu. Kanun numaras1: 5237. Kabul Tarihi: 26/9/2004. Resmi Gazetede Yayımlanma Tarihi: 12/10/2004. Resmi Gazetede Yayımlanma Sayıs1: 25611.

Türk, S. (2010). Öğretmen adayları ile ilköğretim okullarında görev yapan öğretmenlerin çocuk istismarı potansiyeli açısından incelenmesi. Yüksek Lisans Tezi, Sosyal Bilimleri Enstitüsü, Zonguldak Karaelmas Üniversitesi, Zonguldak.

Waid-Lindberg, , C.A., \& Mohr, N.L. (2019). Child sexual abuse. The Encyclopedia of Women and Crime, 1-7

Walker, H. E., Freud, J. S., Ellis, R. A., Fraine, S. M., \& Wilson, L. C. (2017). The prevalence of sexual revictimization. Trauma, Violence, \& Abuse. Advance doi:10.1177/1524838017692364

Walsh, K., Bridgstock, R., Farrella, A., Rassafianib, M., \& Schweitzer, R. (2008). Case, teacher and school characteristics influencing teachers' detection and reporting of child physical abuse and neglect: Results from an Australian survey. Child Abuse \& Neglect, 32(10), 983-993.

Walsh, K., Mathews, B., Rassafiani, M., Farrell, A., \& Butler, D. (2012). Understanding teachers' reporting of child sexual abuse: Measurement methods matter. Children and Youth Services Review, 34, 1937-1946. 
Webster, S.W., O’Toole, R., O’Toole, A.W., \& Lucal, B. (2005). Over reporting and under reporting of child abuse: Teachers' use of professional discretion. Child Abuse \& Neglect, 29(11), 1281-1296.

Yaşar, M. C., Erbasan, Ö., Akçeşme, B., Korkmaz, Ç., \& Gedik, H. (2018). Sınıf öğretmenlerinin çocuğa yönelik cinsel istismar tutumlarının incelenmesi, Jass StudiesThe Journal of Academic Social Science Studies, (73), 1-16.

Yaşar, M.C., Şenol, F. B., \& Akyol, T. (2015). Öğretmen adaylarının çocuğa yönelik cinsel istismar tutumlarının incelenmesi. Hacettepe University Faculty of Health and Sciences Journal, 1(2), 228-241.

Yetiş, O. \& Ziyalar, N. (2018). Çocuk istismarı ve ihmalinin bildirimine yönelik öğretmen tutumlar1. Turkiye Klinikleri Journal of Forensic Medicine and Forensic Sciences, 15(1), 10-23.

\section{İnternet Kaynakçası:}

İHA (2017, 13 Temmuz). "Saadet Öğretmen sağolsun! Tacizciye ceza". Erişim adresi: https://www.hurriyet.com.tr/gundem/saadet-ogretmen-sagolsun-tacizciye-ceza40519093

İHA (2017, 30 Ekim). “Öğretmenin yaptığı anket, cinsel istismarı ortaya çıkardı.” Erişim adresi:https://www.cumhuriyet.com.tr/haber/ogretmenin-yaptigi-anket-cinselistismari-ortaya-cikardi-856307

Saymaz, İ. (2018, 09 Temmuz). "Utanç mektubu: Amcasının tecavüz ettiği 12 yaşındaki kız çocuğu okul koridoruna biraktı." Erişim adresi: https://www.hurriyet.com.tr/gundem/utanc-mektubu-amcasinin-tecavuz-ettigi-12yasindaki-kiz-cocugu-okul-koridoruna-birakti-40890509

\section{Summary}

Statement of Problem: Child abuse or neglect can be described as an intentional damage to children as a result of various actions or inactions of parents or caregivers which are noncompliant with the norms of society about raising children (Polat, 2001). While physical abuse is the most common and the easiest one to detect among abuse types, emotional abuse that damages emotional development of children is accompanied by other abuse types and is the hardest one to notice. On the other hand, sexual abuse is one of the most serious medical, legal and social problems that causes short-term and long-term serious negative and sometimes irreparable consequences (Çeçen, 2007). Child sexual abuse is defined as 
immature child's and adolescent's being involved in an act of sexual satisfaction of an adult, which they cannot fully make sense (Aktepe, 2009). Limited studies on this issue and the number of cases in legal authorities indicates a considerable prevalence of sexual abuse in Turkey (Dönmez et al, 2014; Gündüz \& Y1ldız, 2016). Having a key role in detecting and preventing sexual abuse, it is significant that teacher have skills and competences regarding observing the behavioral changes in child, recognizing the risk factors leading to abuse, reporting abuse and providing rehabilitation. The results of the present studies in the literature showed that the increase in the knowledge and awareness levels of teachers resulted in increase in their attitudes towards reporting sexual abuse. Because of this reason, the studies increasing the awareness of teachers about child abuse and neglect, will be thought contribute regarding detecting, preventing and intervening in sexual abuse.

Purpose of the Study: The present study aims to determine the relationship between the knowledge levels of prospective teachers regarding child abuse and neglect and their attitude levels towards child sexual abuse, and to examine it based on some variables consisting of age, gender and marital status.

Method: The present study uses relational survey model in order to determine the knowledge levels of prospective teachers regarding child sexual abuse and neglect and their attitudes towards child sexual abuse. Participants consist of 515 prospective teachers having pedagogical formation education in the Faculties of Education of Trakya University and Van Yuzuncu Yil University in 2017-2018 educational years. The data was collected through the Survey for Determining the Knowledge Levels of Teachers about Child Abuse and Neglect, Attitude Scale towards Child Sexual Abuse, and Personal Information Form. In data analysis, descriptive statistics in frequency and percentages are used in evaluating demographical features of prospective teachers. The data was analyzed through parametric tests since the data obtained from "Attitude Scale towards Child Sexual Abuse” shows normal distribution. The relationships between variables are analyzed with Pearson correlation test and the presence of difference between scale scores according to demographical variables are questioned with independent samples t-test and AVOVA test.

Findings and Discussions: The present study presents that the moderate level of prospective teachers' knowledge about child abuse and neglect, sexual abuse symptoms and risk factors. A large number of study results (Farrell \& Walsh, 2010; Kenny, 2004; Tugay, 2008) revealed 
that teachers do not have a sufficient level of knowledge about which units to recognize child abuse symptoms and which units they should report to. When a comparison between universities is made; it has been observed that teacher candidates at Trakya University participated in items related to child neglect at higher averages than Van YYU teacher candidates. It is an interesting finding of the research that the level of participation in the same item is highest in one university and lowest in another. This finding can be interpreted as that there is no systematic method for obtaining information with child abuse and neglect, that it is gained randomly, and what is known is different when the information is concrete and clear. The awareness level of society and family has significant effect on child abuse and neglect. While the knowledge level of prospective teachers regarding child abuse and neglect is $60 \%$, their attitude level towards child sexual abuse is $32 \%$, which shows that even though prospective teachers have knowledge about child abuse and neglect, they have low levels of attitude towards reporting it. Negative attitudes of teachers are thought to be related with their concerns about not being supported by administrators (Kenny, 2001), lack of evidence, worrying about harming children, distrusting institutions (Beck, Ogloff \& Corbishley,1994), and the view that the responsibility for detecting and reporting abuses is of school administration and psychological counsellors (Fayez, Takash \& Al- Zboon,2014). Examining comparative findings about the relationship between the knowledge level of prospective teachers regarding child abuse and neglect and their attitude towards sexual abuse, as the knowledge levels of the prospective teachers in Van YYU increase, they are observed to have increased anxiety about reporting child sexual abuse in sub-dimensions. This result suggests that prospective teachers in Van YYU have more negative attitude towards reporting child sexual abuse in liability sub-dimension; i.e. they don't want any liability. High anxiety also indicates low attitude levels towards reporting child sexual abuse. However, the increase in the awareness of prospective teachers in Trakya University results in the increase in the value laden to reporting child sexual abuse, which reveals that as their knowledge level increase, they give more credence to the necessity of reporting it. Examining the relationship between the knowledge levels of all prospective teachers and their attitudes towards reporting child sexual abuse, increases in knowledge level also increase confidence and decrease negative attitude towards reporting child sexual abuse.

Conclusions and Recommendations: In conclusion, prospective teachers should have knowledge about child abuse and neglect in terms of recognizing child victims, appropriately 
approaching child victim and fulfilling legal reporting liabilities. Teachers in school should be fully equipped to conduct protective and preventive actions towards child abuse and neglect. Therefore, based on its results, this study suggests that child abuse and neglect should be taught as a compulsory course in the curriculum of professional teaching knowledge courses in the faculties of education. This will pave the way for prospective teachers to develop positive attitude towards reporting through analyzing and determining problems that create obstacle for them to fulfill their legal liability. The present study is limited with students having pedagogical formation education in the Faculties of Education of Trakya University and Van YYU. Future studies are suggested to examine different sample groups. 